\title{
Environmental assessment of microwaves and the effect of European energy efficiency and waste management legislation
}

Dol:

10.1016/j.scitotenv.2017.11.064

\section{Document Version}

Accepted author manuscript

Link to publication record in Manchester Research Explorer

Citation for published version (APA):

Gallego-Schmid, A., Mendoza, J. M. F., \& Azapagic, A. (2018). Environmental assessment of microwaves and the effect of European energy efficiency and waste management legislation. Science of the Total Environment, 618, 487-499. https://doi.org/10.1016/j.scitotenv.2017.11.064

\section{Published in:}

Science of the Total Environment

\section{Citing this paper}

Please note that where the full-text provided on Manchester Research Explorer is the Author Accepted Manuscript or Proof version this may differ from the final Published version. If citing, it is advised that you check and use the publisher's definitive version.

\section{General rights}

Copyright and moral rights for the publications made accessible in the Research Explorer are retained by the authors and/or other copyright owners and it is a condition of accessing publications that users recognise and abide by the legal requirements associated with these rights.

\section{Takedown policy}

If you believe that this document breaches copyright please refer to the University of Manchester's Takedown Procedures [http://man.ac.uk/04Y6Bo] or contact uml.scholarlycommunications@manchester.ac.uk providing relevant details, so we can investigate your claim.

\section{OPEN ACCESS}


Accepted for publication in Science of The Total Environment 618: 487-499.

doi: 10.1016/j.scitotenv.2017.11.064

\title{
Environmental assessment of microwaves and the effect of European energy efficiency and waste management legislation
}

\author{
Alejandro Gallego-Schmid*, Joan Manuel F. Mendoza and Adisa Azapagic
}

Sustainable Industrial Systems, School of Chemical Engineering and Analytical Science, The University of Manchester, The Mill, Sackville Street, Manchester M13 9PL, UK

Tel. $+44(0) 1613061458$

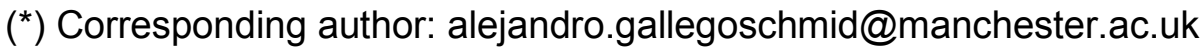

\begin{abstract}
More than 130 million microwaves are affected by European Union (EU) legislation which is aimed at reducing the consumption of electricity in the standby mode ('Standby Regulation') and at more sustainable management of end-of-life electrical and electronic waste ('WEEE Directive'). While legislation focuses on these two life cycle stages, there is little information on the environmental impacts of the entire life cycle of microwaves. To address this gap, this paper presents a comprehensive life cycle assessment of microwaves and assesses the environmental implications of the Standby Regulation and the WEEE Directive at the EU level. The impacts are first considered at the level of individual appliances and then at the EU level, with the aim of evaluating the potential environmental implications of the full implementation of the above two EU regulations by 2020. The effects of the electricity decarbonisation and the expected increase in the number of microwaves in use have also been considered. The results suggest that implementation of the EU regulation by 2020 will reduce the environmental impacts considered by $4 \%-9 \%$ compared to the current situation. The majority of these reductions is due to the Standby Regulation, with the contribution of the WEEE Directive being small $(\sim 0.3 \%)$. However, the expected decarbonisation of electricity will result in much higher reductions (6\%-24\%) for most impact categories. The results also show that materials used to manufacture the microwaves, the manufacturing process and end-of-life disposal are environmental hot-spots for several impacts, including depletion of abiotic elements. Therefore, efforts to reduce the environmental impacts of future electricity mix should be combined with the development of specific eco-design regulations for microwaves that stipulate optimisation of resource consumption. Possible future trends, such as shorter lifetimes and limited availability of some resources, make the development of such product regulations more critical.
\end{abstract}

Keywords: climate change; circular economy; life cycle assessment (LCA); resource consumption; standby regulation; waste of electrical and electronic equipment (WEEE)

\section{Introduction}

Rapid technological developments and falling prices are driving the purchase of electrical and electronic (EE) appliances in Europe (EEA 2014). Consumers also tend to buy new EE appliances before the existing ones reach the end of their useful life as electronic goods have become fashionable and 'status' items (Mansfield 2013). As a result, discarded EE goods are one of the fastest growing waste streams worldwide (EEA 2014). A further issue associated with their growing consumption is the increase of household electricity consumption in most EU countries over the last decade, despite many appliances being more energy efficient (Eurostat, 2016).

EE goods generate environmental impacts in all stages of their life cycle (Andrae and Andersen 2010). This has been demonstrated by many authors who have analysed life cycle impacts of different devices using life cycle assessment (LCA) as a tool. Some examples include LCA studies of plasma TVs carried out by Feng and Ma (2009), Hischier (2015) and Hischier and Baudin (2010). Life cycle impacts of computers have been evaluated by Choi et 
al. (2006), Duan et al. (2009) and Jönbrink (2007). Examples of studies of electrical devices include an LCA of refrigerators (Monfared et al. 2014), dishwashers (Johansson and Björklund 2010), washing machines (Presutto et al. 2007b) and vacuum cleaners (GallegoSchmid et al. 2016).

However, for microwaves, only screening LCA studies have been carried out so far, with most being based on generic or outdated data and assumptions. For instance, Jungbluth (1997) assessed the life cycle environmental performance of different cooking devices, including microwaves, in Switzerland and Germany. The study published generic aggregated inventory data for microwaves, but no specific results were given for the microwaves as the analysis focused on the comparison of electric, gas and wood ovens. Moreover, the inventory data are now 20 years old and can be considered outdated. Another study (Devuono et al. 2000) compared environmental performance of cooktops, ovens and microwaves, but focused only on $\mathrm{CO}_{2}, \mathrm{SO}_{2}$ and $\mathrm{NO}_{\mathrm{x}}$ emissions from electricity consumption in the use stage. In 2002, the National Environmental Technology Information Centre of Korea published the product category rules for microwaves with the aim of developing Environmental Product Declarations (EPDs) from a life-cycle perspective (APEC-VC Korea 2002). A set of general rules were established to make EPDs comparable, but no specific inventory data or guidelines for data collection were included, except for the definition of a standard scenario to calculate the environmental impacts of the use stage. Finally, the Bio Intelligence Service in association with ERA Technology (Mudgal et al. 2011a) performed a technical, environmental and economic analysis of domestic and commercial ovens, as a preparatory study for the development of EU eco-design and energy labelling regulations, both of which aim to improve energy efficiency of energy-using products. In their study, Mudgal et al. (2011a) carried out screening LCA studies for 10 types of electrical oven, including microwaves. Although this work represents the most complete LCA study of microwaves so far, it relied on aggregated inventory data and general assumptions on the consumption of materials and product manufacture. Furthermore, only five environmental impacts were considered (eutrophication, acidification, global warming, ozone layer depletion and primary energy demand), in addition to some air emissions and heavy metals, which were estimated at the inventory level only. The authors concluded that use of microwaves was the only environmentally relevant life cycle stage, suggesting that minimising power consumption in the standby mode was the only cost effective alternative to improving their energy efficiency, as they are a mature product with limited room for additional improvements (Mudgal et al. 2011a). Based on these conclusions, and given that microwaves were already included in the EU regulation (No. 1275/2008) to reduce power consumption in the standby mode (European Commission 2008), they were excluded from the eco-design and energy labelling regulations (Nos. 66/2014 and 65/2014, respectively) for domestic ovens, hobs and range hoods (European Commission 2014a,b) ${ }^{1}$.

However, some other authors have argued that it is likely that the importance of the use stage for the environmental impacts has been overestimated in the European eco-design regulations for some devices, such as televisions, monitors and computers (WRAP 2010; van Rossem and Dalhammar 2010; Huulgaard et al. 2013). As a result, this has obscured the relative importance of other life cycle stages, particularly the production process and the materials used for the manufacture of electrical and electronic devices. To address this issue, WRAP (2010) specifically recommended that life cycle inventory ( $\mathrm{LCl}$ ) for microwaves should be improved for these two life cycle stages. According to the authors, the available $\mathrm{LCl}$ data were limited, incomplete or insufficient, preventing a reliable characterisation of the environmental footprint of these appliances.

The raw materials extraction and processing stages have been gaining importance in recent years in terms of their contribution to the environmental impacts of microwaves. This is due

\footnotetext{
${ }^{1}$ Microwave ovens are only included when associated with an electric or gas domestic oven (i.e. appliances which have 'microwave heating' as a primary cooking function are not included).
} 
to their lower life expectancy, which decreased from 10-15 years in the late 90s to 6.5-8 years nowadays (Dindarian and Gibson 2011; Huisman et al. 2008; Mudgal et al. 2011a). The main reasons for this trend are faster product innovation cycles and the recent EU 'Standby Regulation' to reduce standby electricity consumption in the use stage (European Commission 2008). Given that microwaves account for the largest percentage of sales of all type of ovens in the EU, with a stock of 125 million units in 2007 and a predicted stock of nearly 135 million units by 2020 (Mudgal et al. 2011a), it is increasingly important to start addressing their impact on resource use and end-of-life waste.

The latter is increasing rapidly in many parts of the world. In the EU, 184,000 tonnes of waste electrical and electronic equipment (WEEE) were generated in 2005 from microwave ovens (Huisman et al. 2008) with more than 195,000 tonnes (16 million units) expected to be sent for disposal in 2025 (Mudgal et al. 2011a). To cope with the problem of the growing EE waste, the WEEE Directive provides the European regulatory framework to prevent, re-use, recycle and/or recover this type of waste (European Parliament 2012). It also aims to improve the environmental performance of operators in the supply chain of EE equipment, including producers, distributors and consumers and, in particular, those collecting and treating WEEE. Thus, any achievements in waste prevention and minimisation would contribute directly to improving resource efficiency. The latter underpins the Europe 2020 strategy, which aims to contribute to Europe's smart, sustainable and inclusive economy (European Commission 2010).

However, so far, there has been no comprehensive study of environmental impacts of microwaves over their whole life cycle and hence their environmental impacts beyond the use stage remain largely unknown. Similarly, there is a lack of knowledge about the effects on the impacts of the EU regulation related to reducing energy use in the standby mode and end-of-life waste. To address these gaps, the main goals of this study are:

- to estimate the environmental impacts of the whole life cycle of a microwave, identify life cycle stages that contribute most to the impacts ('hot-spots') and suggest possible improvement options; and

- to assess the implications at the EU level of the implementation of the Standby Regulation (European Commission 2008a) and the WEEE Directive (European Parliament 2012) and provide guidance on future research and policy making.

To our knowledge, this is the first study of its kind internationally.

\section{Methods}

The environmental impacts of microwaves have been evaluated through LCA, following the guidelines specified in the ISO 14040/44 standards (2006a,b). In compliance with these standards, the study followed the four LCA phases: i) goal and scope definition; ii) inventory analysis; iii) impact assessment and iv) interpretation of the results. These stages are described in the next sections.

\subsection{Goal and scope of the study}

In accordance with the goals of the study defined in the introduction (and hence not repeated here), two functional units are considered, one at the product level and another at the EU level:

i) Product level: 'use of a microwave for 1200 use cycles per year consuming $0.056 \mathrm{kWh}$ per cycle over its lifetime of eight years'. This definition corresponds to the EU market specifications provided by Mudgal et al. (2011a) and it has been used to calculate the environmental impacts presented in section 3.1.

ii) The EU level: 'use of all microwaves in the EU28 over one year'. This functional unit is used to assess the implications of the Standby and the WEEE regulations at the EU level, with the results discussed in sections 3.2 and 3.3. The impacts for this functional unit have been estimated by dividing the impacts for the first functional unit by 8 (as the analysis is over one year rather than over the lifetime of the microwave) and multiplying by the total microwave stock in use in the EU28. 
For both functional units, a reference microwave representative of the EU market has been used as described below.

Microwaves can be broadly classified into three categories: conventional, with grill and combined ovens (with conventional and microwave cooking). The European market shows a trend towards the purchase of low-cost conventional microwaves, with a power rating of $1150 \mathrm{~W}$, capacity of around $18 \mathrm{~L}$, with most being produced in South-East Asia (Mudgal et al. 2011a). Therefore, in congruence with the market trends, the focus in this study is on a conventional microwave. The specific model selected for consideration has a rating of 1150 $\mathrm{W}$, capacity of $17 \mathrm{~L}$ and is produced in China.

The system boundaries of the study are from 'cradle to grave' (Fig. 1), comprising the following stages and specific activities considered in the study:

- Production of materials:

- metals: galvanized steel, aluminium, brass, copper, ferrite, tin, lead, gold, nickel, silver, zinc, and palladium;

- plastics: acrylonitrile butadiene styrene (ABS), polyethylene terephthalate (PBT), polyvinyl chloride (PVC), polypropylene (PP), glass fibre reinforced nylon, polystyrene (PS) and polyoxymethylene (POM);

o tempered glass;

- ceramics; and

- cardboard (for packaging).

- Manufacturing of microwaves: metal cold impact extrusion and plastic moulding (in order to obtain the desire shape), production of electronic components (power cord, plug, magnetron, capacitor, transformer, wire cables, lamp and printed control board (PCB)), steel powder painting and curing, product assembly and packaging.

- Use of microwaves: consumption of electricity.

- End-of-life waste management: disposal of post-consumer wastes.

- Distribution: transport of microwave materials and packaging to the manufacturing facility, microwave to retailer and end-of-life waste to the waste management plant. Transport of consumers to purchase the appliance is excluded to avoid the uncertainty associated with allocation of impacts between the microwave and other items that may be purchased at the same time. This also is congruent with the PAS 2050 standard (BSI, 2011) and other recent LCA studies (e.g. Amienyo et al. 2014). 


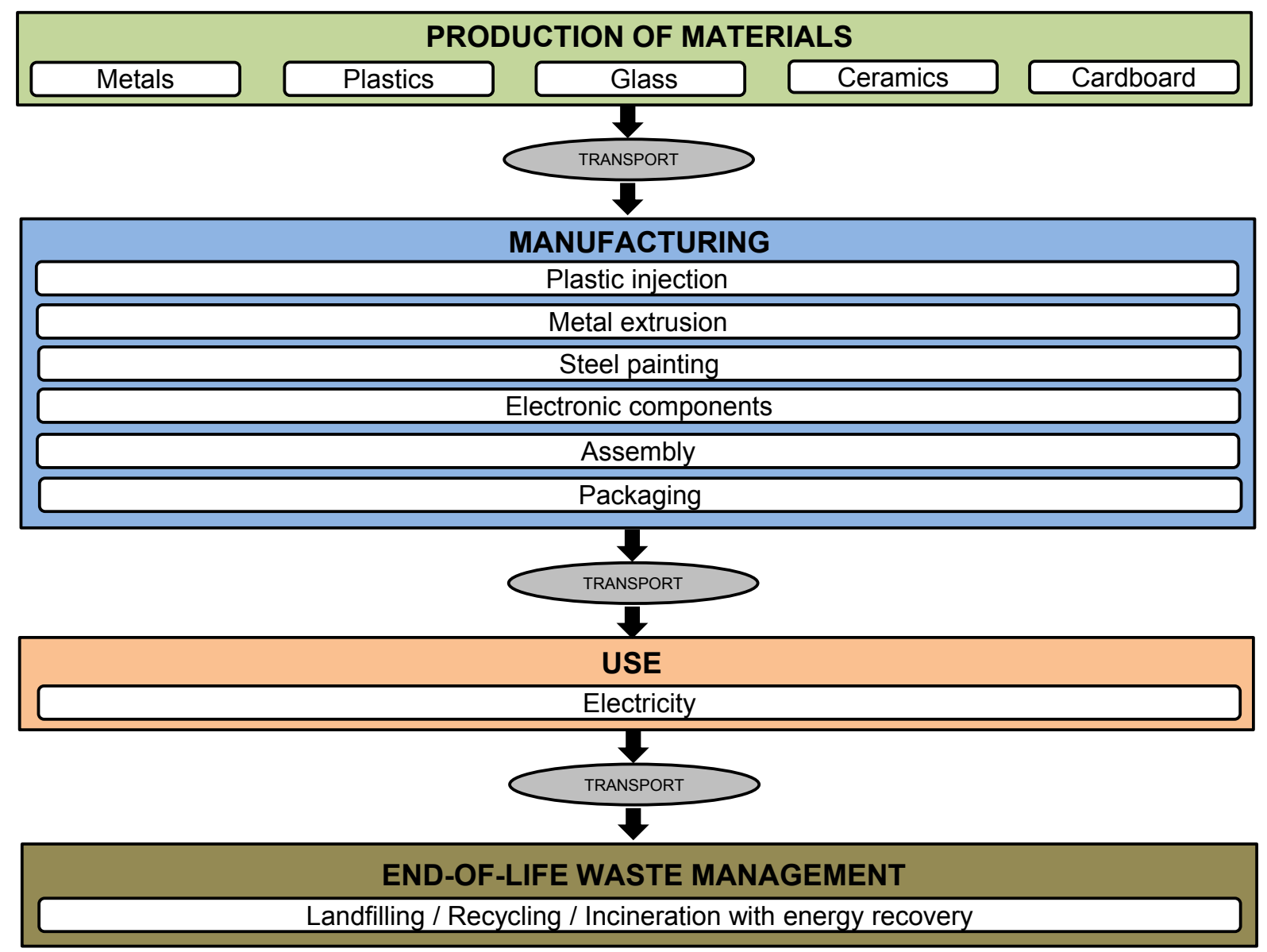

Fig. 1. System boundaries considered in the study

\subsection{Life cycle inventory}

Primary data, including the amount and type of microwave materials and packaging, as well as a detailed description of the manufacturing process, have been obtained from a main microwave supplier. The data on the type and amount of materials used to produce the microwave have been obtained by dismantling the microwave (see Fig. 2). Ecoinvent v2.2 database (Ecoinvent Centre 2010) has been used for the background LCl data for production of materials and packaging, energy generation, transport and waste management. Any data gaps in Ecoinvent have been filled using open literature sources and the GaBi database (Thinkstep 2015). The inventory data are detailed in Table 1 and discussed in the next sections.

\subsubsection{Production of materials and microwaves}

The material composition of the microwave (Table 1) has been determined by weighing the components of the microwave shown in Fig. 2. The metallic components $(8.6 \mathrm{~kg})$ are made of galvanised steel (casing, transformer, magnetron and screws), copper (plug, power cord, wire cables, magnetron, transformer, capacitor), brass (plug), aluminium (magnetron, transformer, capacitor), ferrite (magnets in magnetron) and small amounts of tin, lead, gold, nickel, silver, zinc and platinum (as part of the PCB). The following components are made of plastics $(0.8 \mathrm{~kg})$ : door and control frame (ABS), control mechanism (PBT), power cord and wires (PVC), door frame and fan (PP), printed circuit board (nylon reinforced with glass fibre), turntable moving system (PS) and door locker (POM). Electrical ceramics $(0.07 \mathrm{~kg})$ are used in the magnetron and tempered glass $(1.1 \mathrm{~kg})$, mainly in the door and turntable as well as in the lamp. The background data for these components are from Ecoinvent, with the exception of POM, for which the data are from Plastics Europe (2014) as they are not 
available in Ecoinvent. To account for the manufacture and assembly of the microwave in China, the Ecoinvent data for Chinese electricity have been used for all production processes. Likewise, specific data for manufacturing of materials in China have been used where available; otherwise, worldwide data have been used. Plastic parts are assumed to be produced by injection moulding. Steel and aluminium cold-impact extrusion are considered for shaping these metals and powder painting is used for colouring the casing. Due to a lack of specific data for copper shaping, Ecoinvent data for generic metal shaping have been assumed instead.

The primary packaging of the microwave consists of a folding box, two interior protective cardboards (turntable and main body), four polystyrene foam trays to protect the corners and one polyethylene bag to protect the whole device (Fig. 3). The production of the box has been modelled using inventory data for the folding board and offset printing. Corrugated board data have been assumed for the cardboard. The board protecting the turntable is a double-wall cardboard with mixed fibre and the board protecting the main body is a singlewall cardboard with recycled fibre. Expandable polystyrene has been used to model the polystyrene foam and LDPE film for the plastic bags. The background LCl data for packaging are from the Ecoinvent database.

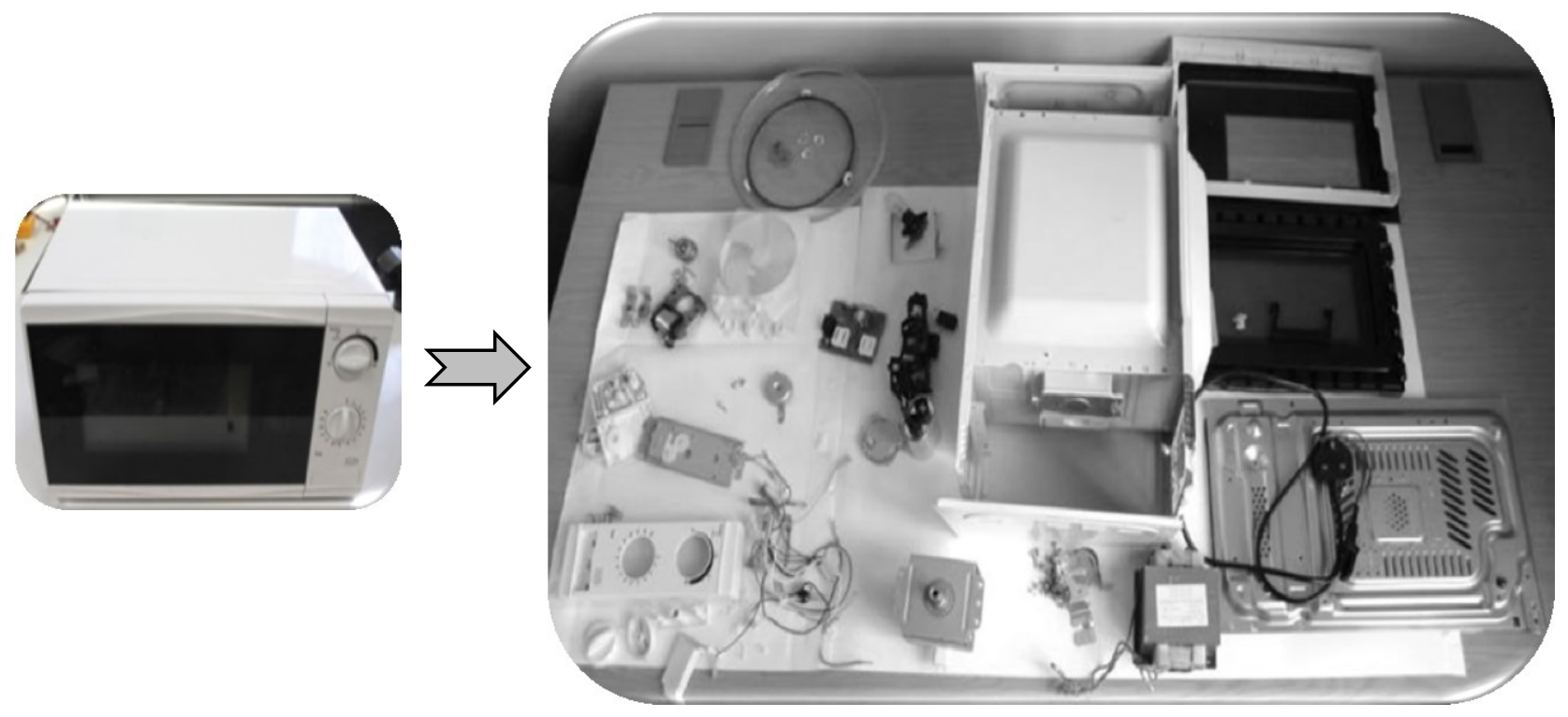

Fig. 2. The microwave and its component parts

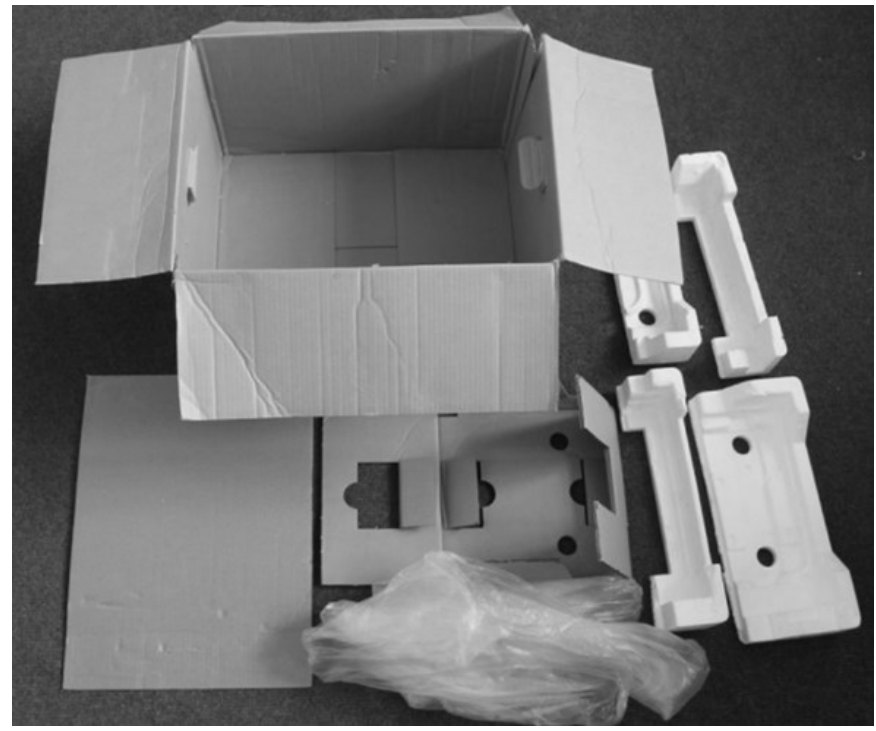

Fig. 3. Primary packaging used for the microwave 
Accepted for publication in Science of The Total Environment 618: 487-499. doi: 10.1016/j.scitotenv.2017.11.064

Table 1. Life cycle inventory data for the reference microwave ${ }^{a}$

\begin{tabular}{|c|c|c|c|}
\hline \multicolumn{4}{|c|}{ Life cycle stages } \\
\hline Production of materials & & Manufacturing of microwaves & \\
\hline Galvanised steel & $7040 \mathrm{~g}$ & Plastics injection moulding (electricity) & $4.2 \mathrm{MJ}$ \\
\hline Copper & $645 \mathrm{~g}$ & Plastics injection moulding (heat) & $3.5 \mathrm{MJ}$ \\
\hline Aluminium & $618 \mathrm{~g}$ & Metal extrusion (electricity) & $11.1 \mathrm{MJ}$ \\
\hline Ferrite & $280 \mathrm{~g}$ & Metal extrusion (heat) & $5.3 \mathrm{MJ}$ \\
\hline Brass & $20 \mathrm{~g}$ & Steel powder painting (electricity) & $6.3 \mathrm{MJ}$ \\
\hline Other metals ${ }^{b}$ & $4.2 \mathrm{~g}$ & Steel powder painting (heat) & $46.7 \mathrm{MJ}$ \\
\hline Acrylonitrile butadiene styrene & $241 \mathrm{~g}$ & Production electronic components (electricity) & $41.1 \mathrm{MJ}$ \\
\hline Polyethylene terephthalate & $167 \mathrm{~g}$ & Production electronic components (heat) & $7.7 \mathrm{MJ}$ \\
\hline Polyvinyl chloride & $162 \mathrm{~g}$ & Assembly and packaging (electricity) & $36.3 \mathrm{MJ}$ \\
\hline Polypropylene & $141 \mathrm{~g}$ & Assembly and packaging (water) & $20.2 \mathrm{~L}$ \\
\hline Nylon & $40 \mathrm{~g}$ & Distribution & \\
\hline Polystyrene & $24 \mathrm{~g}$ & Materials: transport to factory & $0.5 \mathrm{t} k \mathrm{~km}$ \\
\hline Polyoxymethylene & $11 \mathrm{~g}$ & Packaging: transport to manufacturing plant & $0.1 \mathrm{t} \cdot \mathrm{km}$ \\
\hline Glass & $1139 \mathrm{~g}$ & Microwave: factory to Shanghai port & $1.8 \mathrm{t} \cdot \mathrm{km}$ \\
\hline Ceramics & $67 \mathrm{~g}$ & Microwave: Shanghai port to Rotterdam port & $227.6 \mathrm{t} \cdot \mathrm{km}$ \\
\hline Packaging & & Microwave: Rotterdam port to Munich & $9.7 \mathrm{tkm}$ \\
\hline Folding box & $665 \mathrm{~g}$ & Microwave: distribution centre Munich-retailer & $1.8 \mathrm{tkm}$ \\
\hline Protective carton board (single wall) & $157 \mathrm{~g}$ & End of life: transport to waste treatment facility & $1.1 \mathrm{t} k \mathrm{~km}$ \\
\hline Protective carton board (double wall) & $75 \mathrm{~g}$ & Use & \\
\hline Polystyrene foam trays & $165 \mathrm{~g}$ & Electricity & $573 \mathrm{kWh}$ \\
\hline \multirow[t]{11}{*}{ Polyethylene bag } & $12 \mathrm{~g}$ & End-of- life waste treatment & \\
\hline & & Recycling (metals) & $8177 \mathrm{~g}$ \\
\hline & & Recycling (plastics) & $204 \mathrm{~g}$ \\
\hline & & Recycling (paper and plastic packaging) & $753 \mathrm{~g}$ \\
\hline & & Incineration with energy recovery (plastics) & $283 \mathrm{~g}$ \\
\hline & & $\begin{array}{l}\text { Incineration with energy recovery (paper and } \\
\text { plastic packaging) }\end{array}$ & $63 \mathrm{~g}$ \\
\hline & & Landfilling (metals) & $430 \mathrm{~g}$ \\
\hline & & Landfilling (plastics) & $299 \mathrm{~g}$ \\
\hline & & Landfilling (paper and plastic packaging) & $258 \mathrm{~g}$ \\
\hline & & Landfilling (glass) & $1139 \mathrm{~g}$ \\
\hline & & Landfilling (ceramics) & $67 \mathrm{~g}$ \\
\hline
\end{tabular}

To fill data gaps, the following assumptions have been made:

- No specific data were found for PBT production so that data for polyethylene terephthalate have been used instead.

- For the power cord and plug, Ecoinvent data computer cables have been modified as follows. The power cord H05VVH2-F $2 \times 0.75 \mathrm{~mm}^{2}$ has been assumed but, based on own measurements, the amount of copper has been reduced from $19 \mathrm{~g} / \mathrm{m}$ to $14 \mathrm{~g} / \mathrm{m}$. The data for the plug have also been adapted using the actual mass of materials used $(22 \mathrm{~g}$ of PVC, $20 \mathrm{~g}$ of brass and $3 \mathrm{~g}$ of copper).

- Data for the light bulb have been obtained from Elijošiutè et al. (2012).

- For the magnetron, only raw materials extraction and metal-shaping processes have been considered due to a lack of data.

- Data for the metal content in PCB have been obtained from Park and Fray (2009).

- Data for electricity and water consumption during microwave assembly and packing have been sourced from Mudgal et al. (2011a).

- Data for the waste generated in the manufacturing process were not available so the default values from Ecoinvent have been used instead.

\subsubsection{Use of microwaves}

Based on the functional unit defined in 2.1, using the microwave would consume $537.6 \mathrm{kWh}$ of electricity over its lifetime of eight years (1200 cycles/yr at $0.056 \mathrm{kWh} / \mathrm{cycle}$ ). A similar 
average value (563 kWh) was used by APEC-VC Korea (2002) in their standard scenario to characterise the use stage of a conventional microwave. This excludes consumption of electricity in the standby mode. For the latter, the EU Standby Regulation establishes that the maximum standby power rating for microwaves without a digital display, such as the one considered here, should not exceed $0.5 \mathrm{~W}$ for units produced after 2013 (Table 2). Based on this and assuming that the appliance is plugged in over the entire lifetime, the electricity consumption in the standby mode would equal $35 \mathrm{kWh}$. Therefore, a conventional microwave would consume in total $573 \mathrm{kWh}$ during its lifespan. The ENTSO-E (2014a) data have been used for the electricity mix in the EU28 (Table A1 in the Supporting Information). The year 2013 is considered as the base year.

Table 2. Maximum power rating of microwaves in the standby mode depending on the year of manufacture (European Commission 2008)

\begin{tabular}{lcc}
\hline Type of microwave & $2010-2012$ & 2013 onwards \\
\hline Without digital display & $1 \mathrm{~W}$ & $0.5 \mathrm{~W}$ \\
With digital display & $2 \mathrm{~W}$ & $1 \mathrm{~W}$ \\
\hline
\end{tabular}

\subsubsection{End of life waste management}

The following outlines the assumptions for the end-of-life management of the microwave:

- All metals are assumed to be recycled at a rate of $95 \%$ at the end of microwave's lifetime (Kemna et al. 2011; Mudgal et al. 2011a; Xue et al. 2015). Systems expansion has been applied to credit the system for the recycling by subtracting the impacts of the displaced virgin metals and adding the impacts from the recycling process. Congruent with the "net scrap' method (Bergsma and Sevenster 2013), the system has been credited only for the amount of recycled materials that exceeds the recycled content in the original material. For instance, copper has $56 \%$ and $44 \%$ of virgin and recycled material, respectively, so that the system has been credited for recycling $51 \%$ of the metal $(95 \%-44 \%)$. The same method has been used for the other metals. Due to a lack of information on the recycled content in the original materials used to manufacture the microwaves, the recycled content at the global scale has been considered for the different metals as specified in Ecoinvent.

- The waste management data for the plastic materials (PVC, PP, ABS, POM and HDPE) are based on the 2012 data for disposal of plastics in Europe, with 38\% landfilled, 36\% incinerated with energy recovery and $26 \%$ recycled (Plastics Europe 2015). The same approach described above for the metals has been used to credited the system for the recycled plastics. Data from Schmidt (2012) have been used for recycling, assuming that $1.12 \mathrm{~kg}$ of recycled plastic is needed to substitute $1 \mathrm{~kg}$ of virgin plastic, but adapted for the EU28 electricity mix in 2013 (ENTSO-E 2014a). This electricity mix has also been used to credit the system for the recovered electricity from the incineration of plastic waste. The incineration process has been modelled using the $\mathrm{GaBi}$ database (which provides data for integrated electricity and heat recovery, as opposed to Ecoinvent where no energy recovery is considered, with the impacts fully allocated to the waste disposal function). Ecoinvent data have been used for landfilling. Polystyrene foam trays and polyethylene bag have been assumed to be landfilled.

- The type of glass used in the door and turntable is flat glass. The flat glass industry, unlike the container glass sector, uses only internal flat glass cullet generated during the production process (to avoid defects) and therefore external cullet (pre- and postconsumer) is not normally consumed (Neagu-Cogălniceanu and Neagu-Cogălniceanu 2014). Thus, it has been assumed that flat glass is landfilled, which is also in agreement with the current situation described by the association for Europe's manufacturers of flat glass (Glass for Europe 2013).

- For ceramic components, landfilling of inert material has been considered. 
- For cardboard packaging, 2012 packaging disposal data for the EU28 have been assumed (Eurostat 2014): 84\% recycled, 9\% landfilled and 7\% incinerated with energy recovery. Given that the cardboard is produced mainly from recycled material, no environmental credit for the avoided material has been considered in this case.

The WEEE Directive established that the rate of recovery of waste microwaves should be $80 \%$ and at least $75 \%$ of the weight per appliance should be recycled (European Parliament 2012). Based on the assumptions given above on the recycling rates of different materials and their respective weights in the microwave, $82 \%$ of the weight of the microwave is recovered at the end of life, of which $79 \%$ is recycled and $3 \%$ incinerated with energy recovery, in compliance with the Directive.

\subsubsection{Transport}

The transport data are summarised in Table 1. If not specified in the LCA databases, the microwave materials and packaging are assumed to be transported to a distance of $150 \mathrm{~km}$ from the processing plant to the product manufacturing facility by a 16-32 t Euro 3 truck. Production of components from individual microwave materials and the assembly take place at the same location so no transport of the components is considered. A distance of 19,500 $\mathrm{km}$ has been estimated for shipping the microwave by a transoceanic tanker from China (Shanghai) to Europe (Rotterdam). The product is then transported by 16-32 t Euro 5 truck for $830 \mathrm{~km}$ to a distribution centre in Munich (geographically, the central point in the EU). A distance of $150 \mathrm{~km}$ is assumed for road transport (16-32 t Euro 3 truck) from the manufacturing facility to the port in Shanghai and from the distribution centre to the retailer (16-32 t Euro 5 truck). End-of-life waste destined for landfilling is transported by a 16-32 $t$ Euro 5 truck for $50 \mathrm{~km}$ and $100 \mathrm{~km}$ to incineration and recycling facilities. Life cycle inventory data for transport have been sourced from the Ecoinvent database.

\subsubsection{Data and assumptions at the EU level}

This section provides a summary of the data and assumptions used to assess implications of the implementation of the Standby Regulation (European Commission 2008) and the WEEE Directive (European Commission 2012). First, the current situation is considered, taking the year 2013 as a baseline, followed by a future scenario in 2020, representing the year when both regulations are fully implemented. In both cases, the $\mathrm{LCl}$ of the reference microwave has been considered as it is representative of the EU28 market (see section 2.1.), with slight differences in the standby and end-of-life considerations as discussed below. The impacts have been estimated based on the total number of microwaves used over one year in the EU28 countries.

\subsubsection{Current situation}

The key parameters for the current situation, based on the year 2013 , have been estimated as follows:

- Average electricity consumption in the standby mode: Mudgal et al. (2011a) estimated an average value of $2.2 \mathrm{Wh}$ for the standby consumption of a microwave in 2010 at the European level. The maximum power rating set by the Standby Regulation for new microwaves with a digital display sold in the period 2010-2012 is $2 \mathrm{~W}$ (Table 2). In the absence of data on the number of units with and without a digital display, a conservative approach has been taken assuming that all the microwaves have a digital display. Therefore, taking the value estimated by Mudgal et al. and the maximum value prescribed by the Standby Regulation, the average consumption of electricity in the standby mode over an hour assumed here for the base year is equal to $2.1 \mathrm{Wh}$. Microwaves have been considered to be in the standby mode for 24 hours every day over the year ( $8760 \mathrm{~h} / \mathrm{yr}$ ). Therefore, each microwave consumed, on average, $18.4 \mathrm{kWh} / \mathrm{yr}$ in standby in the base year. 
- Electricity mix: The baseline electricity mix in 2013 in the EU28 countries has been considered, as described in section 2.2.2.

- Number of microwaves in use: 131.34 million units (Mudgal et al. 2011a) were available for use in the EU28 in 2013 (Table A2 in the Supporting Information).

- Waste disposal: waste scenarios described in section 2.2.3 have been considered.

\subsubsection{Future scenario}

The following has been assumed for the 2020 scenario:

- Average standby electricity consumption: The maximum power rating in the standby mode set by the Standby Regulation for new devices launched after January 2013 is $1 \mathrm{~W}$ (Table 2). Following the same conservative approach as for the current situation, it has been assumed that all the microwaves sold between 2013-2020 have a digital display; therefore, a power rating of $1 \mathrm{~W}$ in the standby mode. Considering the average value for the standby electricity consumption of $2.1 \mathrm{Wh}$ for the 2013 stock and the rate of substitution of microwaves between 2013-2020 (see Table A2 in the Supporting Information), the average standby consumption over one hour in 2020 is equivalent to $1.06 \mathrm{Wh}$. Therefore, considering that microwaves are in the standby mode for 24 hours every day over the year $(8760 \mathrm{~h} / \mathrm{yr})$, each microwave will consume on average $9.3 \mathrm{kWh} / \mathrm{yr}$ in the standby mode.

- Use stage: As the energy efficiency of microwaves is not likely to improve in the foreseeable future (Mudgal et al. 2011a), the use stage data defined in section 2.2.2 have been considered for the year 2020. Also, the most feasible scenario predicted by ENTSOE (2014b) for EU28 electricity generation in 2020 has been considered for the electricity mix (Table A1 in the Supporting Information).

- Number of microwaves in use: Based on projections by Mudgal et al. (2011a), 134.66 million microwaves will be in use by 2020 in the EU28 countries (Table A2 in the Supporting Information).

- Waste disposal: If the WEEE Directive is fully implemented by 2020 , end-of-life recovery rate of appliances like microwaves should be $85 \%$ and at least $80 \%$ of the total number of microwaves should be recycled. These are higher than the current recovery and recycling rates of $80 \%$ and $75 \%$, respectively (see section 2.2 .3 ). Given that recycling of metals is already high (95\%) and no imminent recycling improvements are expected for flat glass (Glass for Europe 2013), the new recycling targets can only be achieved by focusing on plastic components. In that case, a minimum of $52 \%$ of plastics would have to be recycled and $40 \%$ incinerated with energy recovery. The rest would be landfilled. These rates have been assumed for the plastic materials used for the main body of the microwave (ABS, PBT, PVC, PP, Nylon, PS and POM). The reason for considering the main body only is that the WEEE Directive applies only to the electronic parts of equipment. Waste treatment of packaging is assumed to remain the same in 2020 as at present due to a lack of data and regulation on packaging recycling. A $100 \%$ landfilling of the microwaves is also considered to explore the effects of the WEEE Directive on the environmental impacts.

\subsubsection{Common assumptions for the current situation and the future scenario}

A number of additional assumptions have also been made for the current situation (2013) and the future scenario (2020), as given below:

- The same inventory data for the microwave materials, manufacture, packaging and transportation given in the previous sections have been used to analyse the environmental impacts at the EU level, both for the current situation and in 2020. The inventory data are considered to be accurate for the current situation as the reference microwave is representative of the actual European market. Changes in the design of microwaves to represent the current average standby consumption in 2013 (2.1 Wh) or achieve lower standby consumption by 2020 (1.06 Wh) are minor and hence the 
corresponding changes in the environmental impacts from manufacture, distribution and disposal are considered negligible.

- The same service lifetime (eight years) has been considered for the microwaves for both the current situation and the future scenario. However, as mentioned in the introduction, there has been a trend of reducing the life expectancy of microwaves in recent years (Dindarian and Gibson 2011; Huisman et al. 2008; Mudgal et al. 2011a) that may continue in the future. The effect of this trend has been explored in a sensitivity analysis, by considering a life expectancy of six years in 2020. This is the same lifetime considered by Mudgal et al. (2011a) in their study.

- For end-of-life waste management, the same assumptions are made for all microwaves (see section 2.2.3), with the only difference being the microwave recycling rates at present $(75 \%)$ and in 2020 (80\%). However, their recyclability can vary for different models and countries. To determine the effect of this assumption on the results, the extreme situation of landfilling all waste microwaves in 2020 has been assessed through the sensitivity analysis.

- The study is based on the EU average electricity mix. As the electricity mix varies widely across the EU countries, the effect of this assumption is also explored through the sensitivity analysis by considering electricity mixes in different countries in 2020 . Due to a lack of data on the number of microwaves in use in different countries, the impacts in this part of the sensitivity analysis have been calculated for a single (reference) microwave rather than at the EU level, but considering the electricity mix in each country.

\subsection{Life cycle impact assessment}

The microwave system has been modelled using GaBi 6.5 software (Thinkstep 2015) and the impacts have been estimated according to the CML 2001 (April 2015 version) method (Guinee et al. 2001). The following impacts are considered: primary energy demand (PED), abiotic depletion potential of elements (ADP elements), abiotic depletion potential of fossils $\left(\mathrm{ADP}_{\text {fossil }}\right)$, acidification potential (AP), eutrophication potential (EP), global warming potential (GWP), human toxicity potential (HTP), marine aquatic ecotoxicity potential (MAETP), freshwater aquatic ecotoxicity potential (FAETP), terrestrial ecotoxicity potential (TETP), ozone depletion potential (ODP) and photochemical oxidants creation potential (POCP).

\section{Results and discussion}

This section presents first the results for the reference microwave, followed by the impacts estimated at the EU28 level.

\section{1. $\underline{\text { Reference microwave }}$}

Fig. 4 shows the total environmental impacts of the reference microwave. For example, the microwave will use $8.9 \mathrm{GJ}$ of primary energy and contribute around $416 \mathrm{~kg} \mathrm{CO}$ eq. over its service life. The results in Fig. 4 also indicate that the use stage is the main contributor (over $54 \%$ ) to all impacts categories, except the $\mathrm{ADP}_{\text {elements }}$ to which it contributes only $23 \%$. The consumption of electricity in the standby mode contributes $6 \%$ to the impacts from the use stage or 3\%-5\% to the overall life cycle impacts (except for $A D P_{\text {elements }}$ to which it contributes $<2 \%$ ). The use stage is most significant environmentally due to the high energy consumption over its lifetime relative to the other stages. A further reason is the dominance of fossil fuels and particularly coal in the EU electricity mix (Table A1 in the Supporting Information), which is the major contributor to $\mathrm{ADP}_{\text {fossil }}$, AP, EP, GWP, FAETP, HTP, MAETP and POCP (see Table A3 in the Supporting Information).

The materials used in the manufacture of the microwave are important contributors to $\mathrm{ADP}_{\text {elements }}(67 \%)$; they are also relevant for HTP $(27 \%)$, FAETP $(14 \%)$, MAETP and POCP (13\% each). Most of these impacts are due to the copper used in the electrical cables and electronic parts, except for the $\mathrm{ADP}_{\text {elements }}$ and POCP, where gold and galvanised steel also 
play a major role. The consumption of scarce elements, such as copper and gold, are the main contributors to $A D P_{\text {elements }}(64 \%)$ while emissions to water of heavy metals (e.g. beryllium) during copper mining contribute significantly to FAETP and MAETP ( $8 \%$ and $7 \%$, respectively). Finally, emissions of heavy metals to air (such as arsenic) in the refining process after copper mining and of carbon monoxide during iron sintering (used for galvanised steel) are among the main contributors for HTP and POCP, respectively.

The microwave manufacturing process contributes more than $15 \%$ for 10 out of 12 impact categories, and for AP, ODP and POCP it exceeds 30\%. The production of PCB plays an important role owing to the consumption of electricity in the assembly and the production of the wafer. For the latter, the wastewater from the production process increases the EP while the emission of R22 (chlorodifluoromethane), used in the production of Teflon (polytetrafluoroethylene) for coating the wafer, raises the ODP. During the production of capacitors, methyl ethyl ketone (butanone) is released, which contributes significantly towards POCP.

The overall contribution of transport to the impacts is small $(<2 \%)$. Finally, the end-of-life disposal of the microwaves has a positive effect on most impacts because of the recycling credits, particularly for copper and gold, which affect the $A D P_{\text {elements }}$ and HTP most significantly (Fig. 4).

\subsubsection{Comparison with literature}

As far as we are aware, there are no other comprehensive LCAs studies of microwaves so that like-for-like comparison with literature is not possible. As mentioned in the introduction, there are only three studies of microwaves, two of which (Jungbluth 1997; Devuono et al. 2000) had a different scope to the current study and are based on outdated data; hence, the comparison is not appropriate. The third study (Mudgal et al. 2011a) used recent EU data but also had a different scope and considered only five impact categories. Nevertheless, these are compared in Fig. 5 for four impacts, as the fifth (ODP) was not reported as a numerical value but as "negligible".

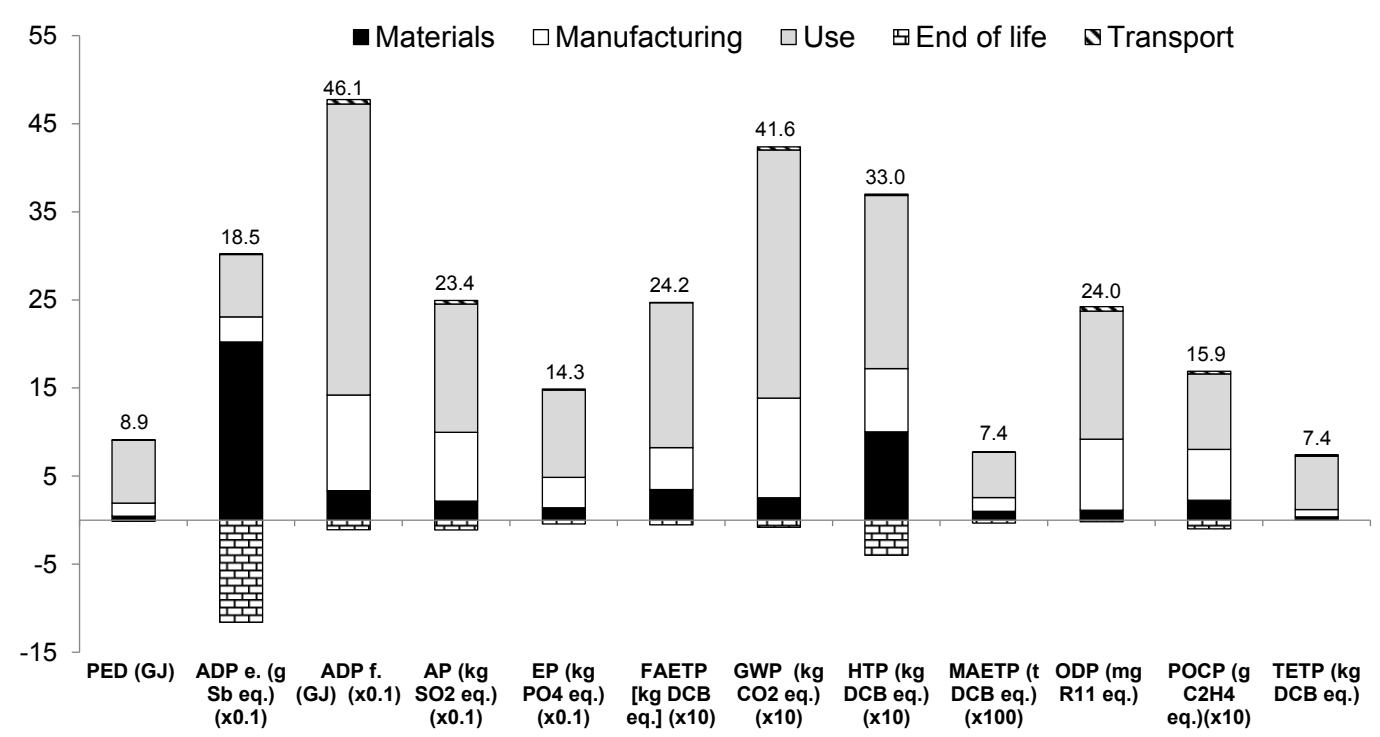

Fig. 4. Life cycle environmental impacts of the reference microwave over the eight-year lifespan [The values given in the graph represent the total impact after the system credits. Some values have been scaled to fit. To obtain the original values, relevant values should be multiplied by the factor shown in brackets. Materials include the packaging. PED: primary energy demand, $A D P_{e} .:$ abiotic depletion potential of elements, $A D P_{f} .:$ abiotic depletion potential of fossil resources, AP: acidification potential, EP: eutrophication potential, GWP: global warming potential, HTP: human toxicity potential, MAETP: marine aquatic ecotoxicity potential, FAETP: freshwater aquatic ecotoxicity potential, ODP: ozone layer depletion potential, POCP: photochemical oxidants creation potential, TETP: terrestrial ecotoxicity potential. DCB: dichlorobenzene.]. 
As can be observed from Fig. 5, there is a good agreement of the results for PED, AP and GWP. This is despite Mudgal et al. (2011a) focusing mainly on the use stage and using general assumptions related to the consumption of materials and product manufacturing. However, the agreement with the results for these three impacts is not surprising after all, because they are dominated by the consumption of electricity in the use stage (see section above). Furthermore, both studies considered the microwave with the same power rating $(1150 \mathrm{~W})$, a lifetime expectancy of eight years and an EU electricity mix. On the other hand, a significant difference can be observed for eutrophication. This is because Mudgal et al. only considered direct water emissions of nutrients, while in the present study, the effect of air emissions (mainly $\mathrm{NO}_{\mathrm{x}}$ from the burning of fossil fuels) is also included.

\subsubsection{Comparison with other EE equipment}

To contextualise the results, this section discusses the environmental impacts of microwaves in relation to those associated with some other types of EE equipment, such as fridges, dishwashers, TVs and computers. Although they all serve a different function, this contextualisation is useful from both the policy-maker and consumer point of view as they are commonly used in households and contribute to the overall impacts in the EU.

The results are summarised in Fig. 6, showing three impacts for which the data were available in the literature: PED, AP and GWP. As can be seen, the microwave has similar impacts to other medium-to-small household devices, such as coffee machines, laptops or vacuum cleaners. The larger devices with longer lifetime expectancies (e.g. refrigerators, dishwasher or washing machines) or with a more intensive use stage (e.g. television) have significantly higher impacts. It can be noted that out of all the EE equipment considered in Fig. 6, microwave is the only device not currently regulated by a specific EU eco-design regulation for energy-related products, because it has the least potential for reducing energy use. However, as the results of this work show, materials are an important contributor to the environmental impacts of microwaves and should be considered in future regulations to minimise resource consumption and increase their circularity. This is discussed further in the next section.

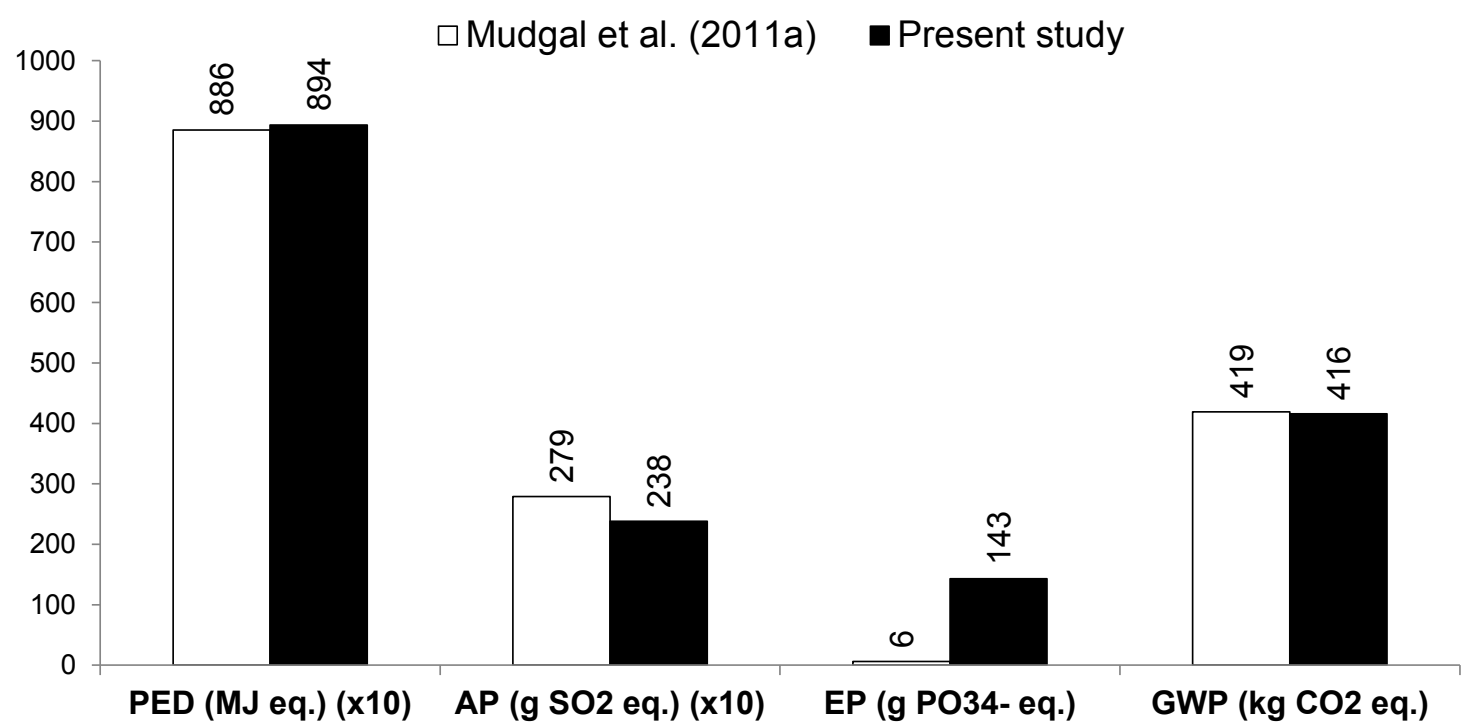

Fig. 5. Comparison of results with the literature. [All impacts refer to the microwave over its eight-year lifespan. The values should be multiplied by the factor shown in brackets for relevant impacts to obtain the original values. For impacts nomenclature, see Fig. 4.] 


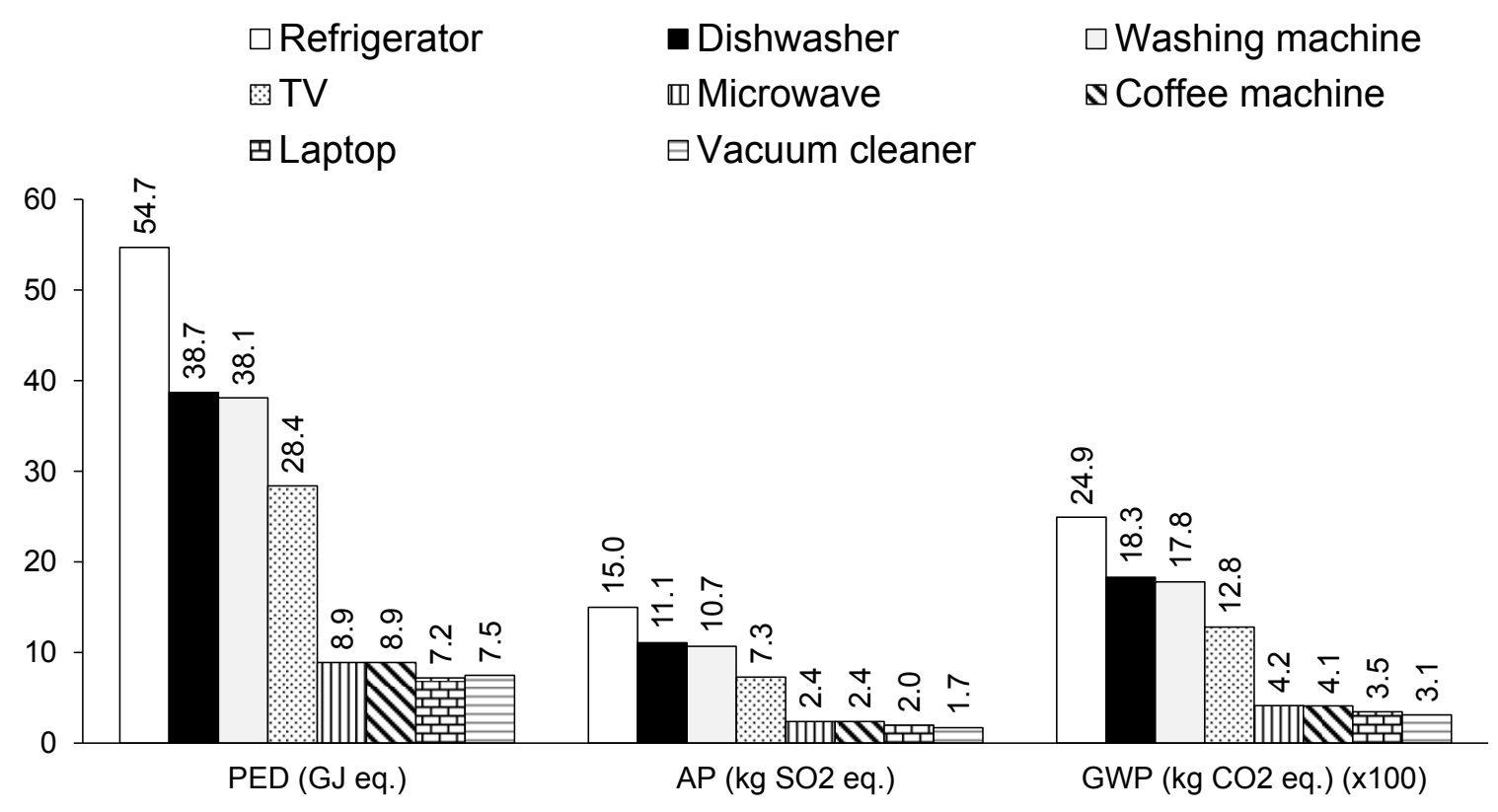

Fig. 6. Environmental impacts of different electronic and electrical equipment. [All impacts from 'cradle to grave'. The values for GWP scaled to fit - to obtain the original value, multiply by 100 . For impacts nomenclature, see Fig. 4. Data sources - Refrigerator, freezer, dishwasher and washing machine: Presutto et al. (2007a,b); TV (LCD): Stobbe (2007); Microwave: present study; Espresso coffee machine (hard cap): Mudgal et al. (2011b); Laptop: Jönbrink (2007); Vacuum cleaner: Gallego-Schmid et al. (2016).]

\subsection{Impacts at the EU level}

Table 3 presents the potential environmental impacts of microwaves used in 2013 and 2020 at the EU28 level. For the latter, the differences in the impacts related to the following four aspects have been considered: the implementation of the Standby and WEEE legislation, the expected changes in the EU electricity mix and the assumed increase in the number of microwaves in use (134.66 million units in 2020 vs 131.34 million in 2013). The results indicate that the reduction in environmental impacts by 2020 related to the application of both EU regulations would be moderate. With the implementation of the Standby Regulation, the environmental impacts would be reduced by $4 \%$ (ADP elements) to $9 \%$ (TETP). The environmental savings related to the implementation of the WEEE Directive would account for only $\sim 0.3 \%$ across all the impact categories. If on the other hand, the expected decarbonisation of EU electricity is achieved by 2020, much greater reductions in the impacts would be achieved in nine out of the 12 categories $(6 \%-24 \%)$, compared to the combined effect of both regulations. However, these reductions would be somewhat countered by the expected increase in the number of units in use of $2.5 \%$.

Nevertheless, the net effect of all of the above four aspects is still positive (the last column of Table 3), with 10 out of 12 impacts decreasing by $6 \%$ (TETP) to $29 \%$ (EP) by 2020 . The GWP is expected to be $15 \%$ lower, saving $1.17 \mathrm{Mt} \mathrm{CO}_{2}$ eq./yr compared to the present situation. This is equivalent roughly to the annual GHG emissions of the Seychelles (JRC, 2014) with $1.25 \mathrm{Mt} \mathrm{CO}_{2}$ eq. in 2012. These savings are due to the decarbonisation of the electricity $\mathrm{mix}(789.6 \mathrm{kt} \mathrm{CO} 2$ eq./yr) and the reduction of the standby energy consumption (566.4 kt CO $\mathrm{CO}_{2}$ eq./yr) related to the implementation of the corresponding $\mathrm{EU}$ regulation. Compared with these reductions, the decrease in the GWP related to the implementation of the WEEE directive is small ( $11 \mathrm{kt} \mathrm{CO} \mathrm{CO}_{2}$ eq./yr) because end-of-life waste management does not contribute much to this impact (see Fig. 4). On the other hand, the expected rise in the number of microwaves would increase the GWP by $2.5 \%$ ( $195.3 \mathrm{kt} \mathrm{CO}_{2}$ eq./yr).

The exceptions to these trends are $\mathrm{ADP}_{\text {elements }}$ and ODP, which increase by around $25 \%$ and $10 \%$, respectively by 2020 compared to today's values. Although the implementation of the 
Standby Regulation reduces $\mathrm{ADP}_{\text {elements }}$ by $4 \%$ compared to the current situation, this is countered by the increase in resource depletion associated with the decarbonisation of the electricity mix (27\%) and the growth in the number of microwaves in $2020(2.5 \%)$. The increase associated with the electricity decarbonisation is due to the higher share of electricity from solar PV, as the PV panels require the use of rare elements, such as tellurium and silver. The decarbonisation of electricity also worsens ODP (14\%), mainly because of a higher relative contribution of natural gas and associated emissions of halons 1211 and 1301, which are used as fire suppressants in the gas pipelines. For further details on the effects of decarbonisation on the impacts see Table A4 in the Supporting Information. The expected improvements in $A D P_{\text {elements }}$ and ODP related to the implementation of the WEEE Directive are negligible $(0.1 \%$ in both cases).

\subsection{Sensitivity analysis}

The following aspects are considered in the sensitivity analysis at the European level to gauge their effect on the environmental impacts:

i) landfilling of microwaves instead of recycling stipulated by the WEEE Directive;

ii) the electricity mix of different EU countries instead of the average EU28 mix; and

iii) reduced lifetime expectancy of microwaves.

\subsubsection{Landfill disposal}

As discussed in the previous section, the implementation of the WEEE Directive would reduce the environmental impacts of microwaves by 2020 , but the reductions would be small compared to those related to the Standby Regulation or the decarbonisation of the electricity mix. Nevertheless, it is also important to analyse the potential effect on the environmental impacts if the WEEE Directive was not implemented. Therefore, it is assumed here that all the microwaves are landfilled instead of recycled.. 
Accepted for publication in Science of The Total Environment 618: 487-499.

doi: 10.1016/j.scitotenv.2017.11.064

Table 3. Influence of different factors on the annual impacts of all microwaves in use at the EU28 level in 2020 relative to the current situation ${ }^{a}$.

\begin{tabular}{|c|c|c|c|c|c|c|}
\hline \multirow[b]{2}{*}{ Impact $^{\mathrm{b}}$} & \multirow[b]{2}{*}{$\begin{array}{c}\text { Current situation } \\
(2013)\end{array}$} & \multicolumn{5}{|c|}{ Future scenario (year 2020) } \\
\hline & & $\begin{array}{l}\text { Differences due to } \\
\text { the Standby } \\
\text { Regulation }\end{array}$ & $\begin{array}{l}\text { Differences due to } \\
\text { the WEEE Directive }\end{array}$ & $\begin{array}{c}\text { Differences due to } \\
\text { Electricity } \\
\text { decarbonisation }^{c}\end{array}$ & $\begin{array}{l}\text { Differences due to the } \\
\text { increase in the number } \\
\text { of microwaves }\end{array}$ & Total $^{c, d}$ \\
\hline PED (PJ/yr) & 170.2 & $-14.3(-8.4 \%)$ & $-0.25(-0.1 \%)$ & $-19.5(-11.4 \%)$ & $4.3(+2.5 \%)$ & $140.5(-17.5 \%)$ \\
\hline $\mathrm{ADP}_{\mathrm{e}}$ (t Sb eq./yr) & 32.8 & $-1.4(-4.3 \%)$ & $-0.03(-0.1 \%)$ & $9.0(+27.3 \%)$ & $0.8(+2.5 \%)$ & $41.2(+25.4 \%)$ \\
\hline$A D P_{f .}(P J / y r)$ & 87.2 & $-6.6(-7.6 \%)$ & $-0.22(-0.3 \%)$ & $-5.6(-6.4 \%)$ & $2.2(+2.5 \%)$ & $77.0(-11.7 \%)$ \\
\hline $\mathrm{AP}\left(\mathrm{kt} \mathrm{SO} \mathrm{S}_{2}\right.$ eq./yr) & 43.8 & $-2.9(-6.7 \%)$ & $-0.04(-0.1 \%)$ & $-7.1(-16.3 \%)$ & $1.1(+2.5 \%)$ & $34.8(-20.5 \%)$ \\
\hline $\mathrm{EP}\left(\mathrm{kt} \mathrm{PO}{ }^{3-}\right.$ eq./yr) & 26.9 & $-2.0(-7.4 \%)$ & $-0.07(-0.2 \%)$ & $-6.3(-23.6 \%)$ & $0.7(+2.5 \%)$ & $19.1(-28.7 \%)$ \\
\hline FAETP (Mt DCB eq./yr) & 4.5 & $-0.3(-7.4 \%)$ & $-0.01(-0.2 \%)$ & $-1.0(-22.8 \%)$ & $0.1(+2.5 \%)$ & $3.2(-27.8 \%)$ \\
\hline GWP (kt $\mathrm{CO}_{2}$ eq./yr) & 7730.8 & $-566.4(-7.3 \%)$ & $-10.96(-0.1 \%)$ & $-789.6(-10.2 \%)$ & $195.3(+2.5 \%)$ & $6559.2(-15.2 \%)$ \\
\hline HTP (Mt DCB eq./yr) & 6.1 & $-0.4(-6.5 \%)$ & $-0.01(-0.1 \%)$ & $-0.6(-10.3 \%)$ & $0.2(+2.5 \%)$ & $5.2(-14.4 \%)$ \\
\hline MAETP (Gt DCB eq./yr) & 13.8 & $-1.0(-7.5 \%)$ & $-0.01(-0.1 \%)$ & $-3.2(-23.3 \%)$ & $0.3(+2.5 \%)$ & $9.9(-28.4 \%)$ \\
\hline ODP (kg R11 eq./yr) & 441.5 & $-29.3(-6.6 \%)$ & $-0.18(-0.1 \%)$ & $61.5(+13.9 \%)$ & $11.2(+2.5 \%)$ & $484.7(+9.8 \%)$ \\
\hline $\mathrm{POCP}\left(\mathrm{kt} \mathrm{C}_{2} \mathrm{H}_{4}\right.$ eq./yr) & 2.9 & $-0.2(-6.0 \%)$ & $-0.01(-0.3 \%)$ & $-0.2(-7.9 \%)$ & $0.1(+2.5 \%)$ & $2.6(-11.6 \%)$ \\
\hline TETP (kt DCB eq./yr) & 140.3 & $-12.2(-8.7 \%)$ & $-0.04(-0.1 \%)$ & $0.1(+0.1 \%)$ & $3.5(+2.5 \%)$ & $131.8(-6.1 \%)$ \\
\hline
\end{tabular}

${ }^{\mathrm{a}}$ Current umber of microwaves: 131.34 million. Assumed number of microwaves in 2020:134.66 million.

${ }^{\mathrm{b}}$ For the impacts nomenclature, see Fig. 4.

${ }^{\mathrm{C}}$ The values in brackets represent the increase (+) or decrease (-) relative to the 2013 values.

${ }^{\mathrm{d}}$ The total value represents the sum of the current impacts and the differences in the impacts due to the different parameters given in the table 
- Future scenario with the WEEE Directive $\square$ Future scenario without the WEEE Directive (100\% landfilling)

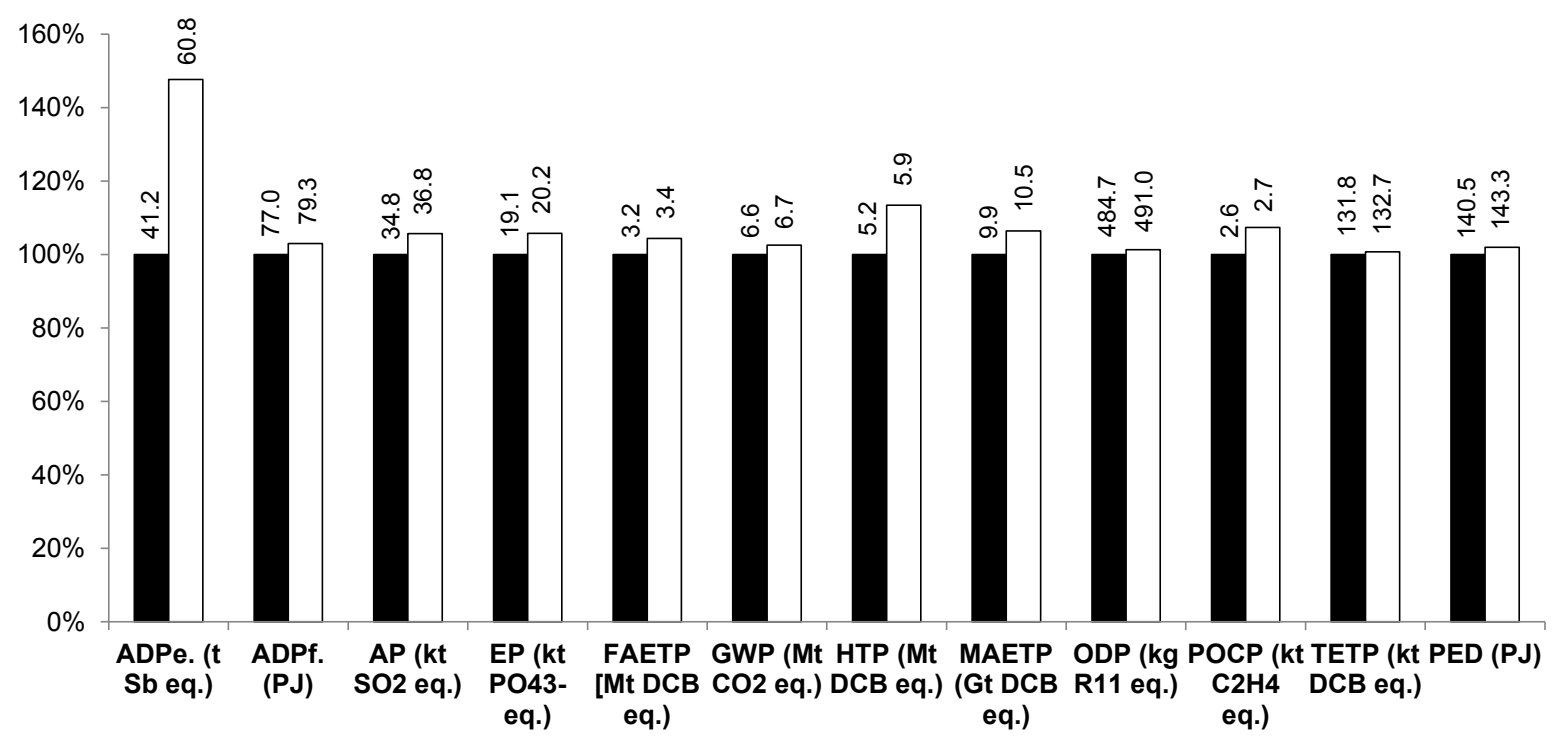

Fig. 7. Annual environmental impacts of all microwaves in 2020 at the EU28 level with and without the WEEE Directive [Basis: 134.66 million units. The values on top of the bars represent the total annual impacts. For the impacts nomenclature, see Fig. 4.]

The results in Fig. 7 suggest that the impacts would increase from 1\% (TETP and ODP) to $48 \%$ ( $A D P_{\text {elements }}$ ). Although the reductions for most impacts but $A D P_{\text {elements }}$ may seem relatively small, the environmental savings at the EU level would be considerable, given the large number of microwaves expected to be in operation by 2020 (134.66 million units). For instance, implementing the WEEE Directive in the EU28 by 2020 would save $11 \mathrm{kt} \mathrm{CO}_{2}$ eq. relative to 2013 but if there was no WEEE Directive, the impact would increase by $167 \mathrm{kt}$ $\mathrm{CO}_{2}$ eq. (see Fig. 7). The latter is equal to the annual GWP of around 148,000 light-duty vehicles, assuming average $\mathrm{CO}_{2}$ emissions of $90 \mathrm{~g} / \mathrm{km}$ and distance travelled of 12,500 $\mathrm{km} / \mathrm{yr}$ (Winkler et al. 2014). For context, the saving of $11 \mathrm{kt} \mathrm{CO} 2$ eq. equates to the annual emissions from 10,000 light-duty vehicles.

The above-mentioned increase in $\mathrm{ADP}_{\text {elements }}$ of almost $50 \%$ suggests that the relative environmental importance of microwave recycling would increase further in the future, particularly if their expected lifespan is reduced, the availability of some resources becomes constrained and a greater decarbonisation of the electricity mix is achieved.

3.3.2. Country specific electricity mix

In the analysis so far, the average EU28 electricity mix has been assumed. Here we explore the effect of the assumed electricity mix on the environmental impacts of microwaves by considering four EU countries with quite different electricity mixes (in 2020):

a) Ireland, where the electricity is dominated by natural gas $(37.7 \%)$;

b) Poland, with mainly coal on the grid $(70.5 \%)$;

c) Denmark, which uses mainly renewables (81.5\%, of which $53 \%$ is wind); and

d) France, where almost half of the electricity $(47.4 \%)$ is from nuclear power plants.

For further details on the above electricity mixes, see Table A1 in the Supporting Information. As mentioned earlier (see section 2.2.5.3), due to a lack of data on the number of microwaves in use in different countries, the impacts have been estimated for one (reference) microwave in year 2020 rather than for the total number of microwaves in the EU. This is deemed appropriate as the aim here is to consider the effect of different electricity mixes rather than the total impacts of microwaves. 
The results indicate that in countries with coal-dominated electricity (e.g. Poland), 10 out of 12 impacts from the microwave are higher than for the EU28 average electricity (Fig. 8). The impacts that increase most (>110\%) are AP, EP, FAETP, GWP and MAETP. In the case of Ireland, which has a greater contribution of natural gas, six impacts are lower in comparison to the EU28 average (ADP elements, EP, FAETP, HTP, MAETP and PED), while the remaining impacts are higher. The electricity profiles of Denmark and France, which are dominated by renewable and nuclear sources, respectively, have significantly lower impacts for 10 impact categories. In both cases, the lower impacts are due to the reduction in the use of fossil fuels, with largest reductions in ADP $_{\text {fossil, }}$ EP, FAETP, GWP, MAETP and ODP. This shows that combining energy efficiency measures, such as those in the Standby Regulation, with electricity decarbonisation can lead to greater overall environmental improvements. It also suggests that countries which are well on the path to decarbonise would benefit less from such regulation.

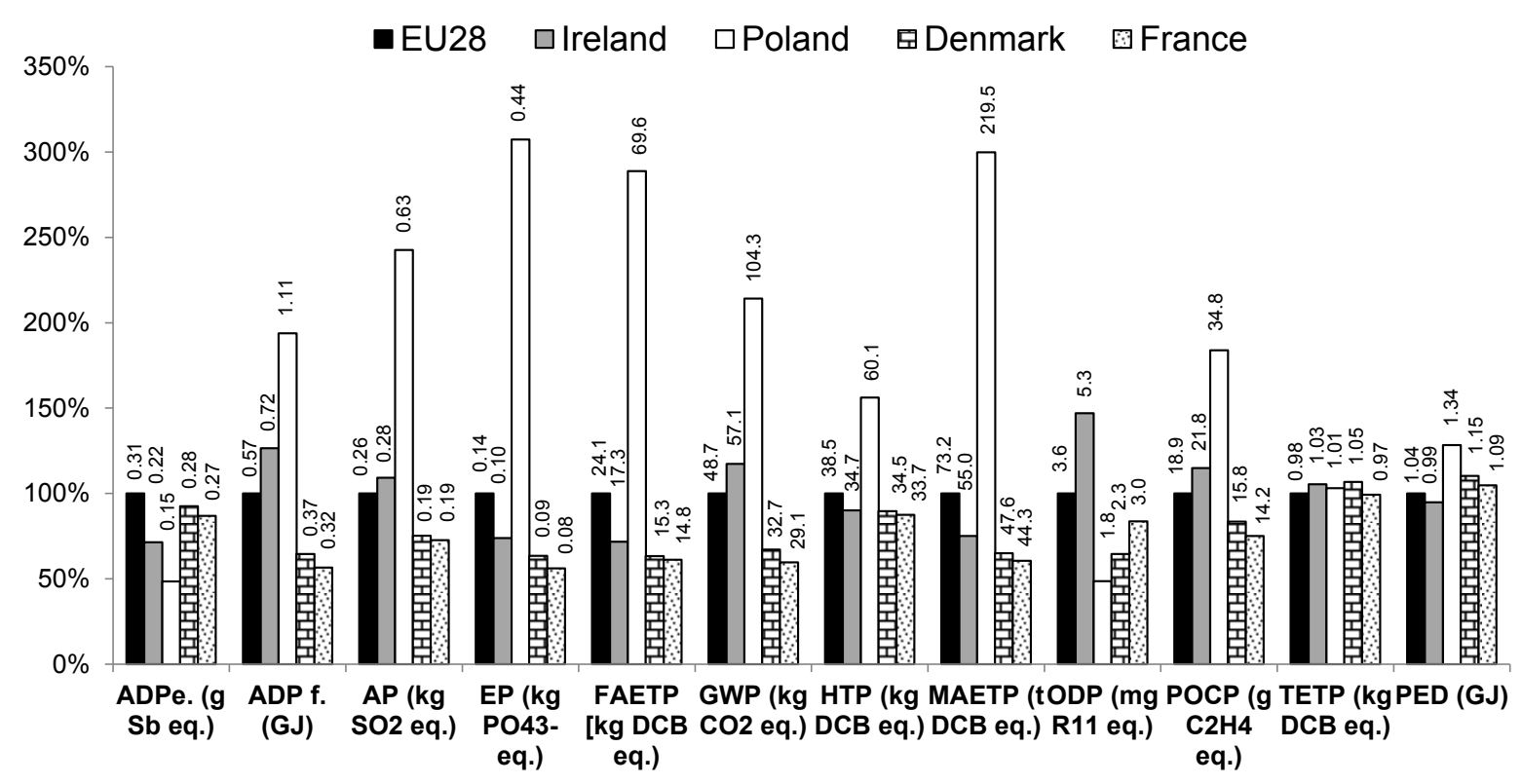

Fig. 8. Annual environmental impacts of an average microwave used in different EU countries in 2020 compared with the EU28 average [Basis: $1150 \mathrm{~W}$ microwave with 1200 cycles/yr, consumption of $0.056 \mathrm{kWh} / \mathrm{cycle}$ and standby consumption of $9.3 \mathrm{kWh} / \mathrm{yr}$. The values on top of the bars represent the total impacts. For the impacts nomenclature, see Fig. 4].

\subsubsection{Lower lifetime expectancy}

As mentioned earlier, there has been a continuous decline in the lifespan of microwaves since the 1990s and this trend may continue in the future. The effect of this trend on the environmental impacts is analysed in this section, assuming a reduction in the lifetime from the current eight to six years in 2020. The results are summarised in Fig. 9 which shows that a decrease in the lifespan would lead to a modest increase in impacts, with the highest increase found for POCP and ADP elements $(16 \%)$ and the lowest for PED (7\%). Given that the impacts are largely dominated by the use stage, these findings may not be surprising. Nevertheless, with the implementation of the energy efficiency measures and electricity decarbonisation, the lifetime of microwaves may become a more influencing factor, together with the other life cycle stages. 


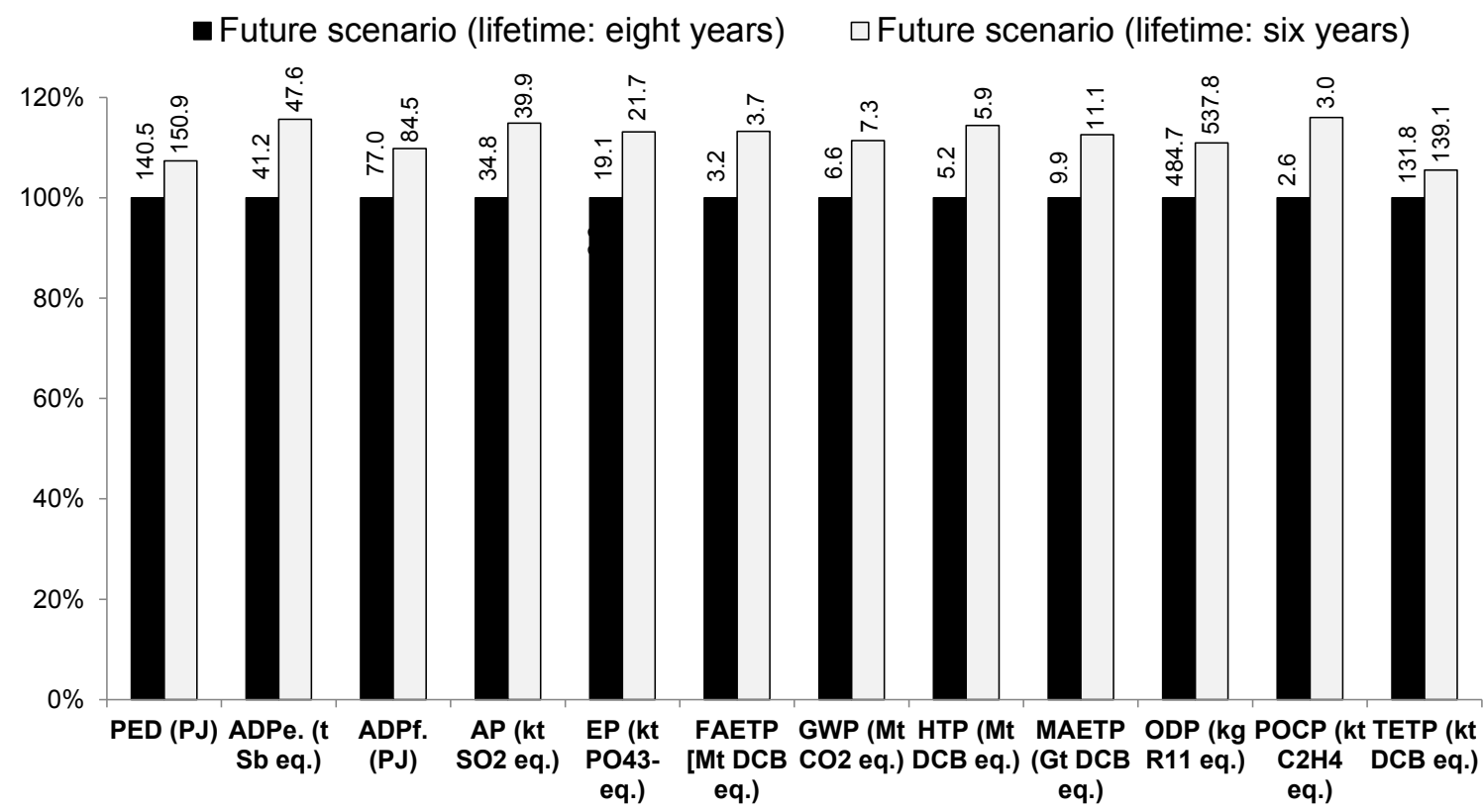

Fig. 9. Influence of the microwave lifespan on the annual environmental impacts at the EU28 level in 2020 [Basis: 134.66 million units. The values on top of the bars represent the total impacts. For the impacts nomenclature, see Fig. 4].

The effect of the latter is considered in

Fig.10 which shows that the materials and microwave manufacture contribute significantly $(>45 \%)$ to seven impacts $\left(\right.$ ADP $_{\text {elements, }}$ AP, EP, FAETP, HTP, MAETP and POCP). The positive contribution of improved end-of-life waste management related to the WEEE Directive is also significant, reducing in particular $\mathrm{ADP}_{\text {elements }}$ by $35 \%$ and HTP by $13 \%$. Therefore, reductions in the lifetime of microwaves and lower carbon intensity of electricity could increase the relative importance of materials, manufacture and end-of-life management. Thus, optimisation of these stages should be an integral part of a strategy for reducing environmental impacts across the life cycle of microwaves (and other EE devices).

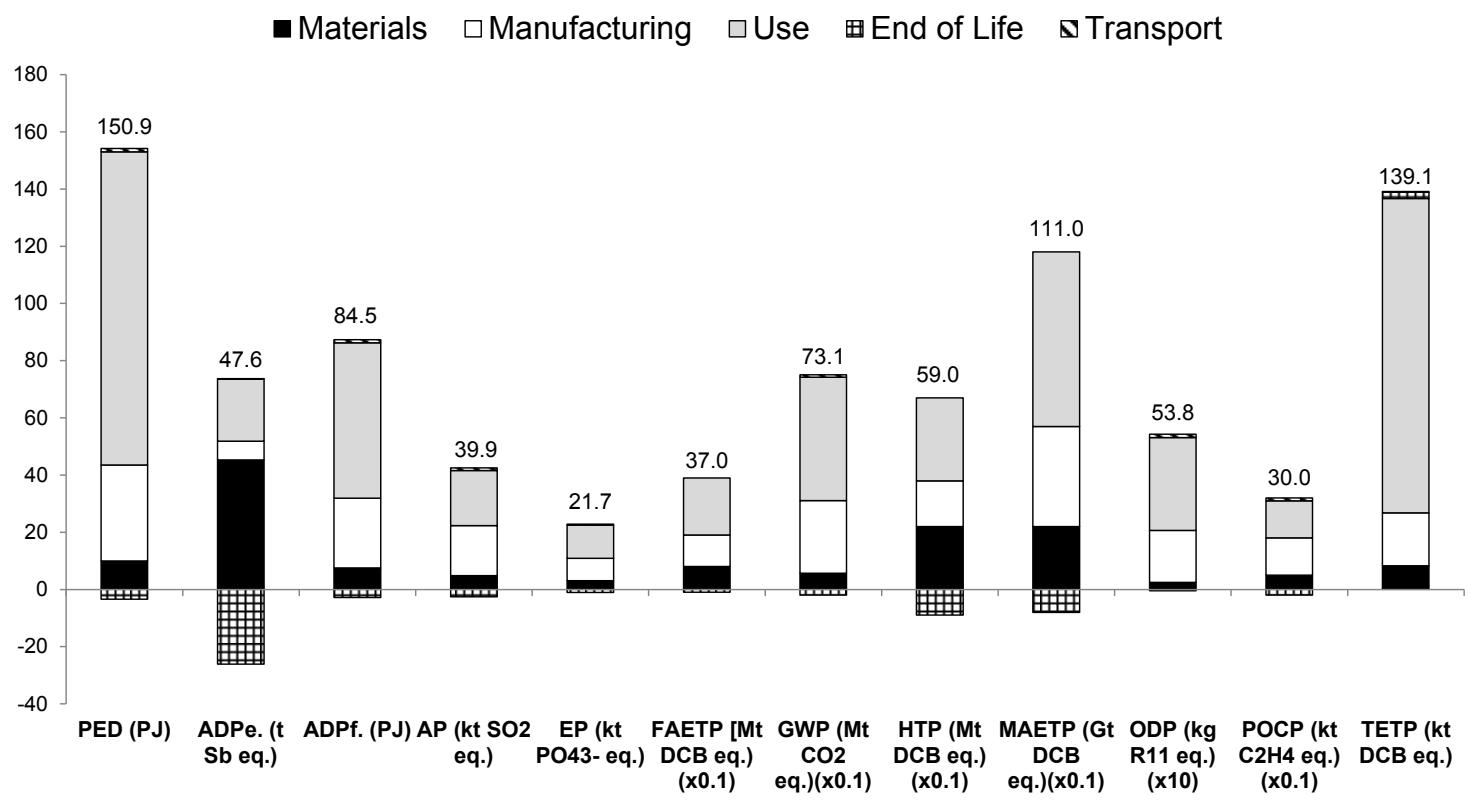

Fig.10. Contribution of different life cycle stage to the annual impacts of the microwaves at the EU28 level in 2020, assuming a lifespan of six years [Basis: 134.66 million units. The values on top of the bars represent the 
Accepted for publication in Science of The Total Environment 618: 487-499. doi: 10.1016/j.scitotenv.2017.11.064

total impacts and should be multiplied by the factor shown in brackets for relevant impacts to obtain the original values. For the impacts nomenclature, see Fig. 4].

\section{Conclusions}

This paper has presented the results of the first comprehensive environmental evaluation of microwaves across the whole life cycle. It has also assessed the environmental implications at the EU level of the implementation of the Standby and WEEE regulations. The results suggest that electricity consumption in the use stage is the main contributor to the environmental impacts. However, the resources used to manufacture the microwaves are the major contributors to the depletion of abiotic elements $(67 \%)$ and play an important role for human and aquatic toxicities as well as for photochemical oxidants creation (13\%-27\%). Furthermore, manufacturing of microwaves also has a relevant contribution to 10 out of the 12 impact categories considered, especially photochemical oxidants (34\%), ozone layer depletion (33\%) and acidification (31\%). End-of-life disposal has an overall positive effect on the environmental impacts due to the credits for recycling, in particular, for depletion of elements and human toxicity. These results demonstrate the need to consider other life cycle stages beyond the use, which has been the focus of the existing studies and policy so far.

At the EU level, the results suggest that all but two environmental impacts (ADP elements and ODP) would be reduced by $6 \%-29 \%$ by 2020 relative to the current situation. Global warming potential is estimated to be lower by $15 \%$. The contribution of the Standby Regulation to these reductions will be modest, ranging from $4 \%$ to $9 \%$. Microwaves are mature products from the energy-efficiency perspective and, therefore, efforts to reduce energy consumption should focus on improving consumer behaviour to use them more efficiently; for example, by adjusting the time of heating to each type of food. The provision of best practices and guidelines by microwave manufactures could help consumers to integrate these into daily practices.

The environmental savings related to the WEEE Directive are much smaller $(\sim 0.3 \%)$ than those from the Standby Regulation. However, without the WEEE Directive, assuming that $100 \%$ of the microwaves are landfilled instead, all impacts would increase. For example, depletion of elements would be higher by $48 \%$, human toxicity by $14 \%$ and creation of photochemical oxidants by $7 \%$. Given the number of microwaves in use, these increases are significant; for instance, global warming potential would be higher by $167,000 \mathrm{t} \mathrm{CO}_{2}$ eq./yr.

The greatest potential for improving the environmental performance of microwaves is related to the expected decarbonisation of the electricity mix in the EU, which would reduce the impacts by $6 \%-24 \%$. The only impacts that would increase because of decarbonisation are depletion of elements (27\%) and the ozone layer (14\%). Thus, policy instruments related to energy efficiency (such as the Standby Regulation) should be complemented by appropriate measures to reduce the impacts from electricity generation. Otherwise, their benefits could be limited.

To improve the environmental footprint of microwaves further, it is also necessary to develop specific regulations for these devices, considering other life cycle stages apart from the use. Possible future trends, such as shorter microwave lifetime, electricity decarbonisation and reduced availability of some materials, will make it even more critical to understand better the effect on the impacts of other life cycle stages, such as production of materials, microwave manufacture and waste treatment. As this study demonstrates, improvements in these parts of the supply chain will result in significant environmental benefits, particularly as the number of microwaves is expected to increase in the future. Therefore, the development of a specific eco-design regulation for microwaves, focused on all the life cycle stages, should be an objective for European authorities in the near future. Related to this, further research should be centred on analysing the potential for eco-design of microwaves. 
Improvements in product resource efficiency through eco-design could contribute to achieving relevant additional environmental savings, together with the energy-efficiency measures. Decoupling resource consumption and environmental impacts from the economic growth is essential to pursuing and shaping a circular economy in Europe and the EE equipment is a key product category that can contribute to it.

\section{Acknowledgments}

This research has been funded by UK Engineering and Physical Sciences Research Council (EPSRC; grant no. EP/K011820/1) and the Sustainable Consumption Institute at the University of Manchester. This funding is gratefully acknowledged. The authors are also grateful to Mr Roy Kershaw for his support in disassembling the microwave.

\section{Appendix A. Supporting information}

The Supporting Information includes data on the electricity mixes in the EU28 and some Member States; stocks and sales of microwaves; environmental hot-spot analysis by life cycle stage; and the environmental profile of the average EU28 electricity.

\section{References}

Amienyo D, Camilleri C, Azapagic A (2014). Environmental impacts of consumption of Australian red wine in the UK. J Clean Prod 72:110-119.

Andrae ASG, Andersen O (2010). Life cycle assessments of consumer electronics-are they consistent? Int J Life Cycle Assess 15(8):827-836.

APEC-VC Korea (2002). PCR Microwave ovens [EDP 2002-188(1)]. Virtual Center for Korean Environmental Technology Exchange, Seoul (South Korea).

Bergsma G, Sevenster M (2013). End-of-life best approach for allocating recycling benefits in LCAs of metal packaging. CE Delft, Delft (The Netherlands).

BSI (2011). Publicly Available Specification PAS 2050:2008. Specification for the Assessment of the Life Cycle Greenhouse Gas Emissions of Goods and Services. British Standards Institution, London (UK).

Choi BC, Shin HS, Lee SY, Hur T (2006). Life cycle assessment of a personal computer and its effective recycling rate Int $J$ Life Cycle Assess 11(2):122-128.

Devuono A, Chan PT, Lutz JD, Marnay C, Rosenquist GJ, McMahon JE (2000). Technical support document for residential cooking products (Docket Number EE-RM-S-97-700). Volume 2: Potential impacts of alternative efficiency levels for residential cooking products. Lawerence Berkeley National Laboratory, Berkeley (USA).

Dindarian A, Gibson AAP (2011). Reuse of EEE/WEEE in UK: Review on functionality of EEE/WEEE at the point of disposal. Proceedings of the 2011 IEEE International Symposium on Sustainable Systems and Technology, 16 May - 18 May 2011, Chicago (USA).

Duan H, Eugster M, Hischier R, Streicher-Porte M, Li J (2009). Life cycle assessment study of a Chinese desktop personal computer. Sci Total Environ 407(5):1755-1764.

Ecoinvent Centre (2010). Ecoinvent v2.2 Database. Swiss Centre for Life Cycle Inventories, Dübendorf, Switzerland.

EEA (2014). Environmental impacts of the production-consumption systems in Europe. European Environment Agency, Copenhagen (Denmark).

Elijošiutè E, Balciukevičiūtè J, Denafas G (2012). Life Cycle Assessment of Compact Fluorescent and Incandescent Lamps: Comparative Analysis. Environ Eng Manag J 3(61):65-72.

ENTSO-E (2014a). ENTSO-E Yearly Statistics \& Adequacy Retrospect 2013. European Network of Transmission System Operators for Electricity, Brussels (Belgium).

ENTSO-E (2014b). Scenario Outlook and Adequacy Forecast (SO\&AF) 2014-2030 Dataset. European Network of Transmission System Operators for Electricity, Brussels (Belgium). 
European Commission (2008). Commission Regulation (EC) No 1275/2008 of 17 December 2008 implementing Directive 2005/32/EC of the European Parliament and of the Council with regard to eco-design requirements for standby and off mode electric power consumption of electrical and electronic household and office equipment. Official Journal of the European Union L 339:45-52.

European Commission (2010) EUROPE 2020: A strategy for smart, sustainable and inclusive growth. Communication of European Commission (COM (2010) 2020 final), Brussels (Belgium).

European Commission (2014a). Commission regulation (EU) No 66/2014 of 14 January 2014 implementing Directive 2009/125/EC of the European Parliament and of the Council with regard to eco-design requirements for domestic ovens, hobs and range hoods. Official Journal of the European Union L 29:33-47.

European Commission (2014b). Commission delegated regulation (EU) No 65/2014 of 1 October 2013 supplementing Directive 2010/30/EU of the European Parliament and of the Council with regard to the energy labelling of domestic ovens and range hoods. Official Journal of the European Union L 29:1-32.

European Parliament (2012). Directive 2012/19EU of the European parliament and of the council of 4 July 2012 on waste electrical and electronic equipment (WEEE). Official Journal of the European Union L 197:38-71.

Eurostat (2014). Packaging waste statistics. http://appsso.eurostat.ec.europa.eu/nui/ show.do?dataset=env_waspac\&lang=en. Accessed 24 April 2017.

Eurostat (2016). Electricity production, consumption and market overview. http://ec.europa .eu/eurostat/statistics-explained/index.php/Electricity_production,_consumption_and_mar ket_overview\#Household_electricity_consumption. Accessed 24 A pril 2017.

Feng $\bar{C}$, Ma XQ (2009). The energy consumption and environmental impacts of a color TV set in China. J Clean Prod 17(1):13-25.

Gallego-Schmid A, Mendoza JMF, Jeswani HK, Azapagic, A (2016). Life cycle environmental impacts of vacuum cleaners and the effect of European regulation. Submitted to Sci Total Environ.

Glass for Europe (2013). Recycling of end-of-life building glass. http://www.glassforeurope .com/images/cont/187_987_file.pdf. Accessed 24 April 2017.

Guinee JB, Gorrèe M, Heijungs R, Huppes G, Kleijn R, van Oers L, Wegener L, Sleeswijk A, Suh S, Udo de Haes HA, de Bruijn H, van Duin R, Huijbregts MAJ (2001). Life Cycle Assessment, an Operational Guide to the ISO Standards. Part 2a: Guide. Kluwer Academic Publishers, Dordrecht (the Netherlands).

Hischier R (2015). Life cycle assessment study of a field emission display television device. Int J Life Cycle Assess 20(1):61-73.

Hischier R. and I. Baudin (2010). LCA study of a plasma television device. Int J Life Cycle Assess 15(5):428-438.

Huisman J, Magalini F, Ruediger K, Claudia M, Delgado C, Artim E, Szlezak J, Ogilvie S, Poll J, Stevels A (2008). Review of Directive 2002/96 on Waste Electrical and Electronic Equipment (WEEE). United Nations University final report, Bonn (Germany).

Huulgaard RD, Dalgaard R, Merciai S (2013). Ecodesign requirements for televisions-is energy consumption in the use phase the only relevant requirement? Int $\mathrm{J}$ Life Cycle Assess 18(5):1098-1105.

ISO (2006a). ISO14040:2006. Environmental management -- Life cycle assessment -Principles and framework. ISO standards, Geneva (Switzerland).

ISO (2006b). ISO14044:2006 Environmental management - Life cycle assessment Requirements and guidelines. ISO standards, Geneva (Switzerland).

Johansson JG, Björklund AE (2010). Reducing life cycle environmental impacts of waste electrical and electronic equipment recycling. J Ind Ecol 14 (2):258-269.

Jönbrink (2007). Lot 3: Personal Computers (desktops and laptops) and Computer Monitors. Preparatory studies for Ecodesign Requirements from EuPs (Tender TREN/D3/91-2007). Final report from IVF Industrial Research and Development Corporation to European Commission (DG ENER), Mölndal (Sweden). 
JRC (2014). Emission Database for Global Atmospheric Research (EDGAR), version 4.2. The EU Joint Research Centre. http://edgar.jrc.ec.europa.eu/overview.php?v=CO2ts\% 201990-2011\&sort=des9. Accessed 24 April 2017.Jungbluth N (1997). Life-CycleAssessment for Stoves and Ovens. UNS Working Paper No. 16, Zurich (Switzerland).

Kemna R, Azaïs N, van Elburg M, van der Voort M, Li W (2011). Part 2: Environmental policies \& data. Methodology for Ecodesign of Energy-related Products. Final report developed from VHK consulters for European Commission, Brussels (Belgium).

Mansfield K (2013). Electronic Waste Disposal in the European Union: Avoiding the Onceler's Dilemma. Research thesis, University of Vermont (USA).

Monfared B, Furberg R, Palm B (2014). Magnetic vs. vapor-compression household refrigerators: A preliminary comparative life cycle assessment. Int J Refrig 42:69-76.

Mudgal S, Tinetti B, Hoa E, Audard G, Robertson C, Goodman P, Pitman S (2011a). Task 5: Definition of Base-case. Lot 22: Domestic and commercial ovens (electric, gas, microwave), including when incorporated in cookers. Preparatory studies for Ecodesign Requirements from EuPs (Tender TREN/D3/91-2007). Final report from Bio Intelligence Service and ERA technology to European Commission (DG ENER), Paris (France).

Mudgal S, Tinetti B, Lyons L, Lavelle P, Cornier A, Sannier C, Jean-Jean A (2011b). Task 5: Definition of Base-case. Lot 25:Non-Tertiary Coffee Machines. Preparatory studies for Ecodesign Requirements from EuPs (Tender TREN/D3/91-2007). Final report from Bio Intelligence Service and ARTS to European Commission (DG ENER), Paris (France).

Neagu-Cogălniceanu C, Neagu-Cogălniceanu I (2014). Thermal embossing method for glass recycling. Adv Mat Res 1036:349-354.

Park YJ, Fray DJ (2009) Recovery of high purity precious metals from printed circuit boards. J Hazard Mater 164:1152-1158.

Plastics Europe (2014). Polyoxymethylene (POM). Eco-profiles and Environmental Product Declarations of the European Plastics Manufacturers. Plastics Europe, Brussels (Belgium).

Plastics Europe (2015). Plastics - the Facts 2014/2015: An analysis of European plastics production, demand and waste data. Plastics Europe, Brussels (Belgium).

Presutto M, Schialdoni R, Mebane W, Faberi S (2007a). Task 5: Definition of Base-case. Lot 13: Domestic refrigerators \& Freezer. Preparatory Studies for Eco-design Requirements of EUPs (Tender TREN/D1/40-2005). Final report from ENEA to European Commission (DG ENER), Ispra (Italy).

Presutto M, Schialdoni R, Cutaia L, Mebane W, (2007b). Task 5: Definition of Base-case. Lot 14: Domestic washing machines and dishwashers. Preparatory Studies for Ecodesign Requirements of EUPs (Tender TREN/D1/40-2005). Final report from ISIS and ENEA to European Commission (DG ENER), Ispra (Italy).

Schmidt JH (2012). Plastberegner.dk- LCA tool for plastics converters in Denmark. Documentation of the tool and database. 2.-0 LCA consultants, Aalborg (Denmark).

Stobbe L (2007). Task 5: Definition of Base-case. Lot 15: Televisions. Preparatory Studies for Eco-design Requirements of EUPs (Tender TREN/D1/40-2005). Final report from Fraunhofer Institute for Reliability and Microintegration to European Commission (DG ENER), Berlin (Germany).

Thinkstep (2015). Gabi 6.5 database. Thinkstep, Leinfelden-Echterdingen (Germany).

van Rossem C, Dalhammar C (2010). Designing greener electronic products: building synergies between EU product policy instruments or simply passing the buck? European Environmental Bureau, Brussels (Belgium).

Winkler SL, Wallington TJ, Maas $\mathrm{H}$, Hass $\mathrm{H}$ (2014). Light-duty vehicle $\mathrm{CO}_{2}$ targets consistent with $450 \mathrm{ppm} \mathrm{CO}_{2}$ stabilization. Environ Impact Asses Rev 48(11):6453-6460

WRAP (2010). Environmental assessment of consumer electronic products. Project code: MDD030. Waste \& Resources Action Programme, Banbury (UK).

Xue M, Kendall A, Xu Z, Schoenung JM (2015). Waste Management of Printed Wiring Boards: A Life Cycle Assessment of the Metals Recycling Chain from Liberation through Refining. Environ Sci Technol 49(2):940-947. 
Accepted for publication in Science of The Total Environment 618: 487-499.

doi: $10.1016 / j . s c i t o t e n v .2017 .11 .064$

\section{Environmental assessment of microwaves and the effect of European energy efficiency and waste management legislation}

Alejandro Gallego-Schmid, Joan Manuel F. Mendoza and Adisa Azapagic

\section{Supporting information}

Table A1. EU electricity mix in 2013 and in 2020

\begin{tabular}{|c|c|c|c|c|c|c|}
\hline Source of electricity & $\begin{array}{r}\begin{array}{r}\text { EU28 } \\
(2013)^{\mathrm{a}}\end{array} \\
{ }^{2}\end{array}$ & $\begin{array}{r}\text { EU28 } \\
(2020)^{b}\end{array}$ & $\begin{array}{l}\text { Poland } \\
(2020)^{\mathrm{b}}\end{array}$ & $\begin{array}{l}\text { France } \\
(2020)^{b}\end{array}$ & $\begin{array}{r}\text { Denmark } \\
(2020)^{\mathrm{b}}\end{array}$ & $\begin{array}{l}\text { Ireland } \\
(2020)^{b}\end{array}$ \\
\hline Nuclear & $29.1 \%$ & $11.8 \%$ & $0.0 \%$ & $47.4 \%$ & $0.0 \%$ & $0.0 \%$ \\
\hline Lignite & $10.3 \%$ & $5.7 \%$ & $18.8 \%$ & $0.0 \%$ & $0.0 \%$ & $1.3 \%$ \\
\hline Hard coal & $17.3 \%$ & $10.8 \%$ & $51.7 \%$ & $4.2 \%$ & $7.7 \%$ & $9.3 \%$ \\
\hline Natural gas & $14.0 \%$ & $20.7 \%$ & $6.1 \%$ & $5.6 \%$ & $10.6 \%$ & $37.7 \%$ \\
\hline Oil & $1.5 \%$ & $2.2 \%$ & $0.0 \%$ & $4.2 \%$ & $0.1 \%$ & $10.0 \%$ \\
\hline Wind & $7.8 \%$ & $18.6 \%$ & $15.1 \%$ & $12.0 \%$ & $53.0 \%$ & $34.6 \%$ \\
\hline Solar & $2.8 \%$ & $11.0 \%$ & $0.0 \%$ & $6.0 \%$ & $7.6 \%$ & $0.9 \%$ \\
\hline Biomass & $4.0 \%$ & $3.6 \%$ & $2.2 \%$ & $1.5 \%$ & $20.9 \%$ & $1.9 \%$ \\
\hline Hydropower (renewable) & $12.2 \%$ & $11.3 \%$ & $1.4 \%$ & $15.9 \%$ & $0.1 \%$ & $2.4 \%$ \\
\hline Hydropower (others) & $1.1 \%$ & $4.4 \%$ & $1.0 \%$ & $3.1 \%$ & $0.0 \%$ & $2.9 \%$ \\
\hline
\end{tabular}

Table A2. Stock and sales for microwave for period 2008/2020 (Mudgal et al. 2011)

\begin{tabular}{ccc}
\hline Year & Stock in use (units) & Sales (units) \\
\hline 2008 & $126,342,972$ & $14,176,712$ \\
2009 & $127,858,076$ & $14,488,600$ \\
2010 & $129,392,373$ & $14,807,349$ \\
2011 & $130,039,335$ & $14,970,230$ \\
2012 & $130,689,532$ & $15,134,903$ \\
2013 & $131,342,979$ & $15,301,386$ \\
2014 & $131,999,694$ & $15,569,702$ \\
2015 & $132,659,693$ & $15,639,868$ \\
2016 & $133,057,672$ & $15,764,985$ \\
2017 & $133,456,845$ & $15,891,107$ \\
2018 & $133,857,215$ & $16,018,236$ \\
2019 & $134,258,787$ & $16,146,382$ \\
2020 & $134,661,563$ & $16,275,553$ \\
\hline
\end{tabular}

Table A3. Hot-spots in the life cycle assessment of a microwave

\begin{tabular}{|c|c|c|c|c|}
\hline Life cycle stage & Impact $^{a}$ & $\begin{array}{c}\text { Contribution } \\
\text { to the total } \\
(\%)\end{array}$ & Main contributor & $\begin{array}{c}\text { Contribution } \\
\text { to life cycle } \\
\text { stage (\%) }\end{array}$ \\
\hline \multirow{4}{*}{ Raw materials: copper } & $\mathrm{ADP}_{\text {elements }}$ & 38.7 & Cu consumption & 83.4 \\
\hline & FAETP & 8.6 & Be (Cu mining) & 31.9 \\
\hline & HTP & 16.2 & As (Cu refining after mining) & 41.1 \\
\hline & MAETP & 7.4 & $\mathrm{Be}$ (Cu mining) & 67.9 \\
\hline \multirow{10}{*}{$\begin{array}{l}\text { Raw materials: gold } \\
\text { Raw materials: } \\
\text { galvanized steel } \\
\text { Production: } \text { PCB }^{\mathrm{b}}\end{array}$} & $\mathrm{ADP}_{\text {elements }}$ & 19.9 & Gold consumption & 99.9 \\
\hline & POCP & 5.9 & $\mathrm{CO}$ (sintered iron) & 49.7 \\
\hline & $\mathrm{ADP}_{\text {fossil }}$ & 9.6 & Fossil fuels (electricity for assembly) & 51.9 \\
\hline & & 16.3 & TOC (wastewater wafer production) & 21.8 \\
\hline & AP & 7.4 & $\mathrm{SO}_{2}$ (coal burning) & 34.7 \\
\hline & FAETP & 10.3 & $\begin{array}{l}\mathrm{Ni} \text { (mining of coal used in electricity } \\
\text { mix for the assembly) }\end{array}$ & 18.2 \\
\hline & GWP & 11.4 & $\begin{array}{l}\mathrm{CO}_{2} \text { (fossil fuels electricity for } \\
\text { assembly) }\end{array}$ & 41.3 \\
\hline & MAETP & 8.4 & $\mathrm{Be}$ (coal mining) & 18.7 \\
\hline & OLD & 22.0 & R22 (Teflon coating) & 21.5 \\
\hline & PED & 8.1 & $\mathrm{U}$ (nuclear energy) & 22.9 \\
\hline Production: capacitor & POCP & 9.1 & Butanone (production capacitors) & 44.7 \\
\hline
\end{tabular}


Accepted for publication in Science of The Total Environment 618: 487-499.

doi: $10.1016 / j . s c i t o t e n v .2017 .11 .064$

Table A3. Continued.

\begin{tabular}{|c|c|c|c|c|}
\hline Life cycle stage & Impact $^{\mathrm{a}}$ & $\begin{array}{c}\text { Contribution } \\
\text { to the total } \\
(\%)\end{array}$ & Main contributor & $\begin{array}{c}\text { Contribution } \\
\text { to life cycle } \\
\text { stage (\%) }\end{array}$ \\
\hline \multirow[t]{2}{*}{$\begin{array}{l}\text { Use: electricity } \\
\text { consumption }\end{array}$} & $A D P_{\text {elements }}$ & 23.4 & Cu (electricity distribution) & 48.7 \\
\hline & $\begin{array}{l}\text { ADP } \text { fossil } \\
\text { AP } \\
\text { EP } \\
\text { FAETP } \\
\text { GWP } \\
\text { HTP } \\
\text { MAETP } \\
\text { ODP } \\
\text { POCP } \\
\text { TETP } \\
\text { PED }\end{array}$ & $\begin{array}{l}69.2 \\
58.4 \\
66.6 \\
66.6 \\
66.5 \\
53.1 \\
66.9 \\
60.1 \\
50.7 \\
83.4 \\
78.1\end{array}$ & $\begin{array}{l}\text { Fossil fuels consumption } \\
\mathrm{SO}_{2} \text { (coal burning) } \\
\mathrm{PO}_{4}{ }^{3-} \text { (coal mining) } \\
\mathrm{Ni} \text { (coal mining) } \\
\mathrm{CO}_{2} \text { (combustion of fossil fuels) } \\
\mathrm{Se} \text { (coal mining) } \\
\mathrm{Be} \text { (coal mining) } \\
\mathrm{Halon} 1211 \text { (natural gas distribution) } \\
\mathrm{SO}_{2} \text { (coal burning) } \\
\mathrm{Cr} \text { (electricity distribution) } \\
\mathrm{U} \text { (nuclear energy) }\end{array}$ & $\begin{array}{l}96.7 \\
81.6 \\
71.7 \\
41.8 \\
82.0 \\
20.1 \\
34.9 \\
55.9 \\
46.4 \\
83.0 \\
33.4\end{array}$ \\
\hline $\begin{array}{l}\text { Disposal: copper } \\
\text { recycling }\end{array}$ & ADP $P_{\text {elements }}$ & -19.3 & Cu consumption (avoided) & -80.2 \\
\hline Disposal: gold recycling & ADP elements & -16.6 & Gold consumption (avoided) & -99.9 \\
\hline
\end{tabular}

Table A4. Environmental impacts of low-voltage electricity consumed in the EU28 countries in 2013 and 2020

\begin{tabular}{|c|c|c|c|c|}
\hline Impact categories ${ }^{a}$ & Unit $^{b}$ & Year 2013 & Year 2020 & Variation $^{c}$ \\
\hline $\mathrm{ADP}_{\text {elements }}$ & mg Sb eq./kWh & 1.2 & 2.1 & $+70.4 \%$ \\
\hline $\mathrm{ADP}_{\text {fossil }}$ & $\mathrm{MJ} / \mathrm{kWh}$ & 5.77 & 5.25 & $-9.1 \%$ \\
\hline AP & $\mathrm{g} \mathrm{SO}_{2}$ eq. $/ \mathrm{kWh}$ & 2.5 & 1.9 & $-26.8 \%$ \\
\hline EP & $\mathrm{g} \mathrm{PO}_{3}{ }^{4-} \mathrm{eq} . / \mathrm{kWh}$ & 1.7 & 1.1 & $-35.2 \%$ \\
\hline FAETP & kg DCB eq./kWh & 0.29 & 0.19 & $-34.2 \%$ \\
\hline GWP & $\mathrm{kg} \mathrm{CO} 2$ eq./kWh & 0.49 & 0.42 & $-15.2 \%$ \\
\hline HTP & kg DCB eq./kWh & 0.34 & 0.28 & $-17.2 \%$ \\
\hline MAETP & kg DCB eq./kWh & 900.89 & 593.60 & $-34.1 \%$ \\
\hline ODP & $\mu \mathrm{g}$ R11 eq./kWh & 250 & 310 & $+23.7 \%$ \\
\hline POCP & $\mathrm{g} \mathrm{C}_{2} \mathrm{H}_{4}$ eq./kWh & 0.15 & 0.13 & $-14.4 \%$ \\
\hline TETP & g DCB eq./kWh & 10.58 & 10.62 & $0.4 \%$ \\
\hline PED & $\mathrm{MJ} / \mathrm{kWh}$ & 12.43 & 10.58 & $-14.9 \%$ \\
\hline
\end{tabular}

a. For impacts nomenclature, see Table A3.

${ }^{b}$ DCB: dichlorobenzene.

${ }^{\mathrm{C}}$ Variation in 2020 relative to 2013 . Positive/negative values indicate an increase/decrease of impacts.

\section{References}

ENTSO-E (2014a). ENTSO-E Yearly Statistics \& Adequacy Retrospect 2013. European Network of Transmission System Operators for Electricity, Brussels (Belgium).

ENTSO-E (2014b). Scenario Outlook and Adequacy Forecast (SO\&AF) 2014-2030 Dataset. European Network of Transmission System Operators for Electricity, Brussels (Belgium).

Mudgal S, Tinetti B, Hoa E, Audard G, Robertson C, Goodman P, Pitman S (2011a). Task 5: Definition of Base-case. Lot 22: Domestic and commercial ovens (electric, gas, microwave), including when incorporated in cookers. Preparatory studies for Ecodesign Requirements from EuPs (Tender TREN/D3/91-2007). Final report from Bio Intelligence Service and ERA technology to European Commission (DG ENER), Paris (France). 